\title{
Evaluation of $\mathrm{K}(\mathrm{HYNIC})_{2}$ as A Bifunctional Chelator for ${ }^{99 m T C-}$ Labeling of Small Biomolecules
}

\author{
Shundong Ji, Yang Zhou, Guoqiang Shao, and Shuang Liu* \\ School of Health Sciences, Purdue University, West Lafayette, Indiana, USA
}

\begin{abstract}
This study sought to evaluate $\mathrm{K}(\mathrm{HYNIC})_{2}(\mathrm{~K}=$ lysine and $\mathrm{HYNIC}=6$-hydrazinonicotinyl $)$ as a bifunctional chelator for ${ }^{99 \mathrm{~m}} \mathrm{Tc}$-labeling of biomolecule. In this study, four $\mathrm{K}(\mathrm{HYNIC})_{2}-$ conjugated cyclic RGD peptides, $\mathrm{K}(\mathrm{HYNIC})_{2}-\mathrm{RGD}_{2}\left(\mathrm{RGD}_{2}=\mathrm{E}[\mathrm{c}(\mathrm{RGDFK})]_{2}\right), \mathrm{K}(\mathrm{HYNIC})_{2}-3 \mathrm{G}-$ $\left.\mathrm{RGD}_{2}\left(3 \mathrm{G}-\mathrm{RGD}_{2}=\text { Gly-Gly-Gly-E[Gly-Gly-Gly-c(RGDfK) }\right]_{2}\right), \mathrm{K}(\mathrm{HYNIC})_{2}-2 \mathrm{P}-\mathrm{RGD}_{2}(2 \mathrm{P}-$ $\mathrm{RGD}_{2}=\mathrm{E}\left[\mathrm{PEG}_{4}-\mathrm{c}(\mathrm{RGDfK})\right]_{2}$, and $\mathrm{PEG}_{4}=15$-amino-4,7,10,13-tetraoxapentadecanoic acid $)$, and $\mathrm{K}(\mathrm{HYNIC})_{2}-3 \mathrm{P}-\mathrm{RGD}_{2}\left(3 \mathrm{P}-\mathrm{RGD}_{2}=\mathrm{PEG}_{4}-\mathrm{E}\left[\mathrm{PEG}_{4}-\mathrm{c}(\mathrm{RGDfK})\right]_{2}\right)$ were prepared, and evaluated for their integrin $\alpha_{v} \beta_{3}$ binding affinity. $\mathrm{IC}_{50}$ values were determined to be $47 \pm 2,35 \pm 2,37 \pm 2$, $85 \pm 2$ and $422 \pm 15 \mathrm{nM}$ for $\mathrm{K}(\mathrm{HYNIC})_{2}-2 \mathrm{P}-\mathrm{RGD}_{2}, \mathrm{~K}(\mathrm{HYNIC})_{2}-3 \mathrm{P}-\mathrm{RGD}_{2}, \mathrm{~K}(\mathrm{HYNIC})_{2}-3 \mathrm{G}-$ $\mathrm{RGD}_{2}, \mathrm{~K}(\mathrm{HYNIC})_{2}-\mathrm{RGD}_{2}$ and $\mathrm{c}(\mathrm{RGDyK})$, respectively, against ${ }^{125}$ I-echistatin bound to U87MG cells. Macrocyclic complexes [ ${ }^{99 \mathrm{~m}} \mathrm{Tc}\left(\mathrm{K}(\mathrm{HYNIC})_{2}-\mathrm{RGD}_{2}\right)$ (tricine)] (1), [ ${ }^{99 \mathrm{~m}} \mathrm{Tc}\left(\mathrm{K}(\mathrm{HYNIC})_{2}-3 \mathrm{G}-\right.$ $\mathrm{RGD}_{2}$ )(tricine)] (2), [ ${ }^{99 \mathrm{~m}} \mathrm{Tc}\left(\mathrm{K}(\mathrm{HYNIC})_{2}-2 \mathrm{P}-\mathrm{RGD}_{2}\right)$ (tricine)] (3), and [ ${ }^{99 \mathrm{~m}} \mathrm{Tc}\left(\mathrm{K}(\mathrm{HYNIC})_{2}-3 \mathrm{P}-\right.$ $\mathrm{RGD}_{2}$ )(tricine)] (4) were prepared, and evaluated in athymic nude mice bearing U87MG glioma xenografts for their tumor targeting capability and biodistribution. It was found that $\mathbf{1}-\mathbf{4}$ all had high solution stability and more than two isomers, as evidenced by the presence of multiple radiometric peaks in their radio-HPLC chromatograms. The tumor uptake of $\mathbf{1}-\mathbf{4}$ was $3.78 \pm$ $0.81,7.46 \pm 1.68,9.74 \pm 1.65$ and $8.59 \pm 1.52 \% \mathrm{ID} / \mathrm{g}$, respectively, which was completely consistent with trend of integrin $\alpha_{v} \beta_{3}$ binding affinity for cyclic RGD peptides. Replacing [ ${ }^{99 \mathrm{~m}} \mathrm{Tc}(\mathrm{HYNIC})$ (tricine)(TPPTS)] (TPPTS = trisodium triphenylphosphine-3,3', $3^{\prime \prime}$-trisulfonate) with [ ${ }^{99 \mathrm{~m}} \mathrm{Tc}\left(\mathrm{K}(\mathrm{HYNIC})_{2}\right)$ (tricine)] had little impact on radiotracer tumor uptake; but it had significant effect on the uptake of radiotracer in kidneys, lungs and spleen. The tumor was clearly visualized by SPECT/CT with excellent contrast in a glioma-bearing mouse administered with 4 . $\mathrm{K}(\mathrm{HYNIC})_{2}$ would be particularly useful for ${ }^{99 \mathrm{~m}} \mathrm{Tc}$-labeling of small biomolecules with one or more disulfide linkages.
\end{abstract}

\section{Keywords \\ $\mathrm{K}(\mathrm{HYNIC})_{2}$; bifunctional chelator; ${ }^{99 \mathrm{~m}} \mathrm{Tc}$-labeling; tumor imaging}

\section{INTRODUCTION}

Since 6-hydrazinonicotinamide (HYNIC) was first reported as a bifunctional coupling agent (BFC) for ${ }^{99 \mathrm{~m}} \mathrm{Tc}$-labeling of polyclonal $\mathrm{IgG}, 1,2$ it has been widely used to label antibodies and other biomolecules (BM) with ${ }^{99 \mathrm{~m}} \mathrm{Tc}^{3-18}$ We have been using a ternary ligand system (Figure $1 A$ : HYNIC, tricine and TPPTS (trisodium triphenylphosphine- $3,3^{\prime}, 3^{\prime \prime}-$

\footnotetext{
*Correspondence should be addressed to: Dr. Shuang Liu, School of Health Sciences, Purdue University, 550 Stadium Mall Drive, West Lafayette, IN 47907, Phone: 765-494-0236, Fax 765-496-1377, liu100@purdue.edu.

Supporting Information Available: Radio-HPLC chromatograms of 4 (Figure SI1) at 1 and $24 \mathrm{~h}$ post-labeling to show its solution stability at room temperature is in word document. This information is available free of charge via the Internet at http://pubs.acs.org.
} 
trisulfonate)) to prepare ${ }^{99 \mathrm{~m}} \mathrm{Tc}$-labeled chemotactic peptides and leukotriene $\mathrm{B}_{4}\left(\mathrm{LTB}_{4}\right)$ receptor antagonists for imaging infection and inflammation, ${ }^{19,20}$ glycoprotein IIb/IIIa receptor antagonists for thrombosis imaging, ${ }^{21}$ and integrin $a_{v} \beta_{3}$ receptor antagonists for tumor imaging. ${ }^{22-25}$ Ternary ligand complexes [99m Tc(HYNIC-BM)(tricine)(TPPTS)] (Figure 1 $A: \mathrm{BM}=$ peptide and non-peptide receptor ligands) were prepared with high specific activity, and had very high solution stability. ${ }^{19-25}$ Their composition has been determined to be 1:1:1:1 for Tc:HYNIC:tricine:TPPTS through a series of mixed ligand experiments, ${ }^{26}$ and further confirmed by LC-MS at the tracer $\left({ }^{99 \mathrm{~m}} \mathrm{Tc}\right)$ and macroscopic $\left({ }^{99} \mathrm{Tc}\right)$ levels. ${ }^{27}$ The utility of HYNIC has been reviewed extensively. ${ }^{28-30}$

Previously, we reported HYNIC-K(NIC) ( $\omega$-nicotinyl-2-(6-hydrazinonicotinyl)lysine) as a BFC for ${ }^{99 \mathrm{~m}} \mathrm{Tc}-$ labeling of biomolecules, and found that HYNIC-K(NIC) was able to form a macrocyclic chelate $\left[{ }^{99 \mathrm{~m}} \mathrm{Tc}(\mathrm{HYNIC}-\mathrm{K}(\mathrm{NIC}))\right.$ (tricine)] (Figure $1 B$ ) with high solution stability. ${ }^{31} \mathrm{We}$ also found that replacing [99m Tc(HYNIC)(tricine)(TPPTS)] with $\left[{ }^{99 \mathrm{~m}} \mathrm{Tc}\left(\mathrm{HYNIC}-\mathrm{K}(\mathrm{NIC})\right.\right.$ )(tricine)] resulted in less uptake in kidneys and lungs for ${ }^{99 \mathrm{~m}} \mathrm{Tc}$ radiotracers. ${ }^{32}$ These promising results inspired us to evaluate K(HYNIC)2 as a BFC for ${ }^{99 \mathrm{~m}} \mathrm{Tc}$-labeling of cyclic RGD peptides. We reasoned that $\mathrm{K}(\mathrm{HYNIC})_{2}$ and HYNIC$\mathrm{K}(\mathrm{NIC})$ would form macrocyclic ${ }^{99 \mathrm{~m}} \mathrm{Tc}$ complexes with a similar structure except that one of two HYNIC groups in $\mathrm{K}$ (HYNIC) 2 might be bidentate (Figure $1 C$ ). Since $\mathrm{SnCl}_{2}$ is used

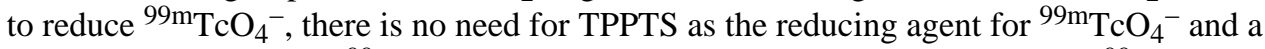
coligand to stabilize the ${ }^{99 \mathrm{~m}} \mathrm{Tc}-\mathrm{HYNIC}$ core. This is particularly important for ${ }^{99 \mathrm{~m}} \mathrm{Tc}$ labeling of small biomolecules with one or more disulfide linkages, which could be readily reduced by TPPTS at elevated temperatures.

As a continuation of our interest in radiolabeled cyclic RGD peptides as integrin $a_{v} \beta_{3^{-}}$ targeted radiotracers for tumor imaging, ${ }^{32-41}$ we have prepared four $\mathrm{K}(\mathrm{HYNIC})_{2}$-conjugated cyclic RGD peptides: $\mathrm{K}(\mathrm{HYNIC})_{2}-\mathrm{RGD}_{2}\left(\mathrm{RGD}_{2}=\mathrm{E}[\mathrm{c}(\mathrm{RGDfK})]_{2}\right), \mathrm{K}(\mathrm{HYNIC})_{2}-3 \mathrm{G}-\mathrm{RGD}_{2}$ $\left.\left(3 \mathrm{G}-\mathrm{RGD}_{2}=\text { Gly-Gly-Gly-E[Gly-Gly-Gly-c }(\mathrm{RGDfK})\right]_{2}\right), \mathrm{K}(\mathrm{HYNIC})_{2}-2 \mathrm{P}-\mathrm{RGD}_{2}\left(2 \mathrm{P}-\mathrm{RGD}_{2}\right.$ $=\mathrm{E}\left[\mathrm{PEG}_{4}-\mathrm{c}(\mathrm{RGDfK})\right]_{2}$, and $\mathrm{PEG}_{4}=15$-amino-4,7,10,13-tetraoxapentadecanoic acid $)$, and $\mathrm{K}(\mathrm{HYNIC})_{2}-3 \mathrm{P}-\mathrm{RGD}_{2}\left(3 \mathrm{P}-\mathrm{RGD}_{2}=\mathrm{PEG}_{4}-\mathrm{E}\left[\mathrm{PEG}_{4}-\mathrm{c}(\mathrm{RGDfK})\right]_{2}\right)$. An in vitro whole-cell assay was used to determine their integrin $a_{\mathrm{v}} \beta_{3}$ binding affinity against ${ }^{125}$ I-echistatin bound to U87MG human glioma cells. We also prepared macrocyclic complexes $\left[{ }^{99 \mathrm{~m}} \mathrm{Tc}\left(\mathrm{K}(\mathrm{HYNIC})_{2}-\mathrm{RGD}_{2}\right)\right.$ (tricine)] (1), [ ${ }^{99 \mathrm{~m}} \mathrm{Tc}\left(\mathrm{K}(\mathrm{HYNIC})_{2}-3 \mathrm{G}-\mathrm{RGD}_{2}\right)$ (tricine)] (2), $\left[{ }^{99 \mathrm{~m}} \mathrm{Tc}\left(\mathrm{K}(\mathrm{HYNIC})_{2}-2 \mathrm{P}-\mathrm{RGD}_{2}\right)\right.$ (tricine)] (3) and [99m $\mathrm{Tc}\left(\mathrm{K}(\mathrm{HYNIC})_{2}-3 \mathrm{P}-\mathrm{RGD}_{2}\right)$ (tricine)] (4), and evaluated them in the athymic nude mice bearing U87MG glioma xenografts for their tumor-targeting capability and biodistribution characteristics. The objective of this study is to explore the potential of $\mathrm{K}(\mathrm{HYNIC})_{2}$ as a BFC, and compare the three chelating systems (Figure 1: A - C) with respect to the isomerism and biodistribution of the ${ }^{99 \mathrm{~m}} \mathrm{Tc}-$ labeled of cyclic RGD peptides (Figure 1: $1-6)$.

\section{EXPERIMENTAL SECTION}

\section{Materials and Instruments}

Chemicals and solvents were purchased from Sigma-Aldrich (St. Louis, MO). Cyclic peptides, $\mathrm{E}[\mathrm{c}(\mathrm{RGDfK})]_{2}\left(\mathrm{RGD}_{2}\right), \mathrm{G}_{3}-\mathrm{E}\left[\mathrm{G}_{3} \text {-c }(\mathrm{RGDfK})\right]_{2}\left(3 \mathrm{G}-\mathrm{RGD}_{2}\right), \mathrm{E}\left[\mathrm{PEG}_{4}-\mathrm{c}(\mathrm{RGDfK})\right]_{2}$ $\left(2 \mathrm{P}-\mathrm{RGD}_{2}\right)$ and $\mathrm{PEG}_{4}-\mathrm{E}\left[\mathrm{PEG}_{4}-\mathrm{c}(\mathrm{RGDfK})\right]_{2}\left(3 \mathrm{P}-\mathrm{RGD}_{2}\right)$ were obtained from the Peptides International, Inc. (Louisville, KY). Sodium succinimidyl 6-(2-(2sulfonatobenzaldehyde)hydrazono)nicotinate (HYNIC-OSu) was prepared according to literature method. ${ }^{42}\left[{ }^{99} \mathrm{~m} \mathrm{Tc}\left(\mathrm{HYNIC}-3 \mathrm{P}-\mathrm{RGD}_{2}\right)\right.$ (tricine)(TPPTS)] (5) [99m $\mathrm{Tc}(\mathrm{HYNIC}-$ $\mathrm{K}(\mathrm{NIC})-3 \mathrm{P}-\mathrm{RGD}_{2}$ )(tricine)] (6) were prepared using the procedures described in our previous reports. ${ }^{32,33} \mathrm{Na}^{99 \mathrm{~m}} \mathrm{TcO}_{4}$ was obtained from Cardinal HealthCare ${ }^{\circledR}$ (Chicago, IL). Electrospray ionization (ESI) mass spectra were collected on a Finnigan LCQ mass spectrometer, School of Pharmacy, Purdue University. 


\section{HPLC Methods}

The semi-prep HPLC method (Method 1) used a LabAlliance HPLC system (Scientific Systems, Inc., State College, PA) equipped with a UV/vis detector $(\lambda=254 \mathrm{~nm})$ and Zorbax $\mathrm{C}_{18}$ column (9.4 mm x $250 \mathrm{~mm}, 100 \AA$ A pore size; Agilent Technologies, Santa Clara, CA). The flow rate was $2.5 \mathrm{~mL} / \mathrm{min}$ with a gradient mobile phase going from $90 \% \mathrm{~A}(0.1 \%$ TFA in water) and $10 \% \mathrm{~B}(0.1 \% \mathrm{TFA}$ in acetonitrile) at $0 \mathrm{~min}$ to $30 \% \mathrm{~B}$ at $5 \mathrm{~min}$, and $50 \% \mathrm{~B}$ at 18 min. The radio-HPLC (Method 2) used the LabAlliance HPLC system equipped with a $\beta$ ram IN/US detector (Tampa, FL) and Zorbax $\mathrm{C}_{18}$ column $(4.6 \mathrm{~mm}$ x $250 \mathrm{~mm}, 300 \AA$ A pore size; Agilent Technologies, Santa Clara, CA). The flow rate was $1 \mathrm{~mL} / \mathrm{min}$. The gradient mobile phase started with $90 \% \mathrm{~A}\left(25 \mathrm{mM} \mathrm{NH}_{4} \mathrm{OAc}, \mathrm{pH}=6.8\right)$ and $10 \% \mathrm{~B}$ (acetonitrile) to $85 \% \mathrm{~A}$ and $15 \% \mathrm{~B}$ at $5 \mathrm{~min}$, followed by a gradient mobile phase going from $15 \% \mathrm{~B}$ at 5 $\min$ to $20 \% \mathrm{~B}$ at $20 \mathrm{~min}$ and to $60 \% \mathrm{~B}$ at $25 \mathrm{~min}$.

Lys(Boc) $)_{2}-\mathbf{E}[\mathbf{c}(\mathbf{R G D f K})]_{2}\left(\mathrm{~K}\left(\mathrm{Boc}_{2}\right)_{2}-\mathbf{R G D}_{2}\right)-\mathrm{K}(\mathrm{Boc})_{2}-\mathrm{OSu}(8.8 \mathrm{mg}, 20 \mu \mathrm{mol})$ and $\mathrm{RGD}_{2}(13.2 \mathrm{mg}, 10 \mu \mathrm{mol})$ were dissolved in DMF $(2 \mathrm{~mL})$. After addition of DIEA (50 $\mu \mathrm{mol})$, the reaction mixture was stirred at room temperature for $5 \mathrm{~h}$. The reaction was terminated by adding $2 \mathrm{~mL}$ of $\mathrm{NH}_{4} \mathrm{OAc}$ buffer $(100 \mathrm{mM}, \mathrm{pH}=7.0)$, the product was separated by semi-prep HPLC (Method 1). The fractions at 15.3 min were collected. Lyophilization of the collected fractions afforded $\mathrm{K}(\mathrm{Boc})_{2}-\mathrm{RGD}_{2}$. The yield was $11 \mathrm{mg}$ $(\sim 67 \%)$. ESI-MS: $m / z=1646.5$ for $[\mathrm{M}+\mathrm{H}]^{+}\left(\mathrm{M}=1645.86\right.$ calcd. for $\left.\left[\mathrm{C}_{75} \mathrm{H}_{115} \mathrm{~N}_{21} \mathrm{O}_{21}\right]\right)$.

Lys-E[c(RGDfK) $]_{2}\left(\mathbf{K}-\mathbf{R G D}_{\mathbf{2}}\right)-\mathrm{K}(\mathrm{Boc})_{2}-\mathrm{RGD}_{2}(3.3 \mathrm{mg}, 2 \mu \mathrm{mol})$ was dissolved in anhydrous trifluoroacetic acid (TFA, $1 \mathrm{~mL}$ ). After stirring at room temperature for 5-10 min, excess TFA was removed on a rotary evaporator. The residue was dissolved in $2 \mathrm{~mL}$ of water. The product was isolated by semi-prep HPLC (Method 1). Fractions at 11.4 min were collected and combined. Lyophilization of the resulting solution afforded the expected product K-RGD 2 as its TFA salt. The yield was $2.1 \mathrm{mg}(\sim 62 \%)$. ESI-MS: $m / z=1446.8$ for $[\mathrm{M}+\mathrm{H}]^{+}\left(\mathrm{M}=1445.75\right.$ calcd. for $\left.\left[\mathrm{C}_{65} \mathrm{H}_{99} \mathrm{~N}_{21} \mathrm{O}_{17}\right]\right)$.

Lys(HYNIC) $)_{2}$-E[c(RGDfK) $]_{2}$ (K(HYNIC) ${ }_{2}-$ RGD $\left._{2}\right)$-HYNIC-OSu $(4.6 \mathrm{mg}, 10 \mu \mathrm{mol})$ and $\mathrm{K}-\mathrm{RGD}_{2}(2.9 \mathrm{mg}, 2.0 \mu \mathrm{mol})$ were dissolved in DMF $(1 \mathrm{~mL})$. After addition of excess DIEA $(40 \mu \mathrm{mol})$, the reaction mixture was stirred at room temperature for 7 days. Upon addition of $2 \mathrm{~mL}$ ammonium acetate buffer $(100 \mathrm{mM}, \mathrm{pH}=7.0)$ to terminate the reaction, the product was separated by semi-prep HPLC method (Method 1). The fractions at $17.8 \mathrm{~min}$ were collected. Lyophilization of the collected fractions afforded $\mathrm{K}(\mathrm{HYNIC})_{2}-\mathrm{RGD}_{2}$. The yield was $1.5 \mathrm{mg}(\sim 37 \%)$. ESI-MS: $\mathrm{m} / \mathrm{z}=2053.3$ for $[\mathrm{M}+\mathrm{H}]^{+}$and 1027.5 for $[\mathrm{M}+\mathrm{H}]^{2+}(\mathrm{M}=$ 2051.82 calcd. for $\left.\left[\mathrm{C}_{91} \mathrm{H}_{117} \mathrm{~N}_{27} \mathrm{O}_{25} \mathrm{~S}_{2}\right]\right)$.

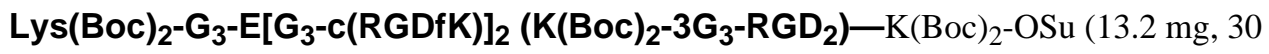
$\mu \mathrm{mol})$ and $3 \mathrm{G}^{-R_{\mathrm{RD}}}(18.3 \mathrm{mg}, 10 \mu \mathrm{mol})$ were dissolved in DMF $(2 \mathrm{~mL})$. After adding excess DIEA $(50 \mu \mathrm{mol})$, the reaction mixture was stirred at room temperature for $5 \mathrm{~h}$. After addition of $2 \mathrm{~mL}$ water, the $\mathrm{pH}$ was then adjusted to 4.0 with TFA. The product was isolated from the mixture using the same HPLC method used for $\mathrm{K}(\mathrm{Boc})_{2}-\mathrm{RGD}_{2}$. The fractions at 14.5 min were collected. Lyophilization of the collected fractions afforded $\mathrm{K}(\mathrm{Boc})_{2}-3 \mathrm{G}_{3}-$ $\mathrm{RGD}_{2}$. The yield was $10.4 \mathrm{mg}(48 \%)$. ESI-MS: $\mathrm{m} / z=2159.9$ for $[\mathrm{M}+\mathrm{H}]^{+}(\mathrm{M}=2159.05$ calcd. for $\left.\left[\mathrm{C}_{93} \mathrm{H}_{142} \mathrm{~N}_{30} \mathrm{O}_{30}\right]\right)$.

Lys- $\mathbf{G}_{\mathbf{3}}-\mathbf{E}\left[\mathrm{G}_{\mathbf{3}}-\mathbf{c}(\mathbf{R G D f K})\right]_{\mathbf{2}}\left(\mathbf{K}-\mathbf{3} \mathrm{G}_{\mathbf{3}}-\mathbf{R G D}_{\mathbf{2}}\right)$-K(Boc) $)_{2}-3 \mathrm{G}_{3}-\mathrm{RGD}_{2}(4.3 \mathrm{mg}, 2 \mu \mathrm{mol})$ was dissolved in anhydrous trifluoroacetic acid (TFA, $1 \mathrm{~mL}$ ). After stirring at room temperature for 5-10 min, excess TFA was removed on a rotary evaporator. The residue was dissolved in $2 \mathrm{~mL}$ of water. The product was isolated by semi-prep HPLC (Method 1). The fractions at 9.5 min were collected and combined. Lyophilization of the combined fractions afforded the 
expected product $\mathrm{K}-3 \mathrm{G}_{3}-\mathrm{RGD}_{2}$ as its TFA salt. The yield was $3.5 \mathrm{mg}(\sim 89 \%)$. ESI-MS: $\mathrm{m} / \mathrm{z}$ $=2160.6$ for $[\mathrm{M}+\mathrm{H}]^{+}\left(\mathrm{M}=1958.95\right.$ calcd. for $\left.\left[\mathrm{C}_{83} \mathrm{H}_{126} \mathrm{~N}_{30} \mathrm{O}_{26}\right]\right)$.

Lys(HYNIC) $)_{2}-\mathbf{G}_{\mathbf{3}}-\mathbf{E}\left[\mathrm{G}_{\mathbf{3}}-\mathrm{C}(\mathrm{RGDfK})\right]_{\mathbf{2}}\left(\mathrm{K}(\mathrm{HYNIC})_{2}-\mathbf{3 G}_{\mathbf{3}}-\mathbf{R G D}_{\mathbf{2}}\right.$ )—HYNIC-OSu (4.6 mg, $10 \mu \mathrm{mol})$ and $\mathrm{K}-3 \mathrm{G}_{3}-\mathrm{RGD}_{2}(1.96 \mathrm{mg}, 1.0 \mu \mathrm{mol})$ were dissolved in anhydrous DMF $(1 \mathrm{~mL})$. After addition of excess $(50 \mu \mathrm{mol})$, the reaction mixture was stirred at room temperature for 7 days. Upon addition of $2 \mathrm{~mL} \mathrm{NH} \mathrm{N}_{4} \mathrm{OAc}$ buffer $(100 \mathrm{mM}, \mathrm{pH}=7.0)$, the product was separated from the mixture using the same HPLC method for $\mathrm{K}(\mathrm{HYNIC})_{2}-\mathrm{RGD}_{2}$. The fractions at $15.6 \mathrm{~min}$ were collected and combined. Lyophilization of the resulting solution afforded $\mathrm{K}(\mathrm{HYNIC})_{2}-3 \mathrm{G}_{3}-\mathrm{RGD}_{2}$. The yield was $1.2 \mathrm{mg}(47 \%)$. ESI-MS: $\mathrm{m} / \mathrm{z}=2567.8$ for $[\mathrm{M}+\mathrm{H}]^{+}$and 1582.2 for $[\mathrm{M}+\mathrm{H}]^{2+}\left(\mathrm{M}=2565.01\right.$ calcd. for $\left.\left[\mathrm{C}_{109} \mathrm{H}_{144} \mathrm{~N}_{36} \mathrm{O}_{34} \mathrm{~S}_{2}\right]\right)$.

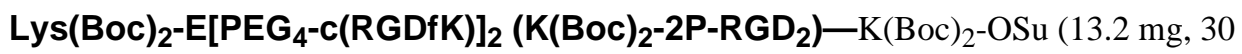
$\mu \mathrm{mol})$ and $2 \mathrm{P}-\mathrm{RGD}_{2}(18.3 \mathrm{mg}, 10 \mu \mathrm{mol})$ were dissolved in DMF $(2 \mathrm{~mL})$. After addition of excess DIEA $(50 \mu \mathrm{mol})$, the reaction mixture was stirred at room temperature for $5 \mathrm{~h}$. Upon addition of $2 \mathrm{~mL} \mathrm{NH}_{4} \mathrm{OAc}$ buffer $(100 \mathrm{mM}, \mathrm{pH}=7.0)$, the product was separated using the same method for $\mathrm{K}(\mathrm{Boc})_{2}-\mathrm{RGD}_{2}$. The fractions at 14.7 min were collected. Lyophilization of collected fractions afforded $\mathrm{K}(\mathrm{Boc})_{2}-2 \mathrm{P}-\mathrm{RGD}_{2}$. The yield was $13.4 \mathrm{mg}(\sim 63 \%)$. ESI-MS: $m / z=2141.0$ for $[\mathrm{M}+\mathrm{H}]^{+}\left(\mathrm{M}=2140.14\right.$ calcd. for $\left.\left[\mathrm{C}_{97} \mathrm{H}_{157} \mathrm{~N}_{23} \mathrm{O}_{31}\right]\right)$.

Lys-E[PEG $\mathbf{4}_{\mathbf{4}} \mathbf{c}(\mathbf{R G D f K})_{\mathbf{2}}$ (K-2P-RGD $\left.\mathbf{2}\right)-\mathrm{K}(\mathrm{Boc})_{2}-2 \mathrm{P}-\mathrm{RGD}_{2}(2.14 \mathrm{mg}, 1 \mu \mathrm{mol})$ was dissolved in anhydrous trifluoroacetic acid (TFA, $1 \mathrm{~mL}$ ). After stirring at room temperature for 5-10 min, excess TFA was removed on a rotary evaporator. The residue was dissolved in $2 \mathrm{~mL}$ of water. The product was isolated by semi-prep HPLC (Method 1). Fractions at 11.3 min were collected. Lyophilization of the collected fractions afforded the expected product K-2P-RGD 2 . ESI-MS: $m / z=2188.5$ for $[\mathrm{M}+\mathrm{H}]^{+}(\mathrm{M}=2187.18$ calcd. for $\left.\left[\mathrm{C}_{98} \mathrm{H}_{162} \mathrm{~N}_{24} \mathrm{O}_{32}\right]\right)$.

Lys(HYNIC) ${ }_{2}$ E[PEG ${ }_{4}$-c(RGDfK) $]_{2}$ (K(HYNIC) ${ }_{2}$-2P-RGD ${ }_{2}$ - - HYNIC-OSu (4.6 mg, 10 $\mu \mathrm{mol})$ and $\mathrm{K}-2 \mathrm{P}-\mathrm{RGD}_{2}(2.2 \mathrm{mg}, 1.0 \mu \mathrm{mol})$ were dissolved in DMF $(1 \mathrm{~mL})$. After addition of DIEA $(50 \mu \mathrm{mol})$, the reaction mixture was stirred at room temperature for 7 days. The reaction was terminated by adding $2 \mathrm{~mL}$ of $\mathrm{NH}_{4} \mathrm{OAc}$ buffer $(100 \mathrm{mM}, \mathrm{pH}=7.0)$, the product was separated using the same HPLC method for $\mathrm{K}(\mathrm{HYNIC})_{2}-\mathrm{RGD}_{2}$. The fractions at $20.4 \mathrm{~min}$ were collected. Lyophilization of the collected fractions afforded the expected product $\mathrm{K}(\mathrm{HYNIC})_{2}-2 \mathrm{P}-\mathrm{RGD}_{2}$. The yield was $1.7 \mathrm{mg}(\sim 61 \%)$. ESI-MS: $\mathrm{m} / \mathrm{z}=2546.9$ for $[\mathrm{M}+\mathrm{H}]^{+}$and 1274.4 for $[\mathrm{M}+\mathrm{H}]^{2+}\left(\mathrm{M}=2546.10\right.$ calcd. for $\left.\left[\mathrm{C}_{113} \mathrm{H}_{159} \mathrm{~N}_{29} \mathrm{O}_{35} \mathrm{~S}_{2}\right]\right)$.

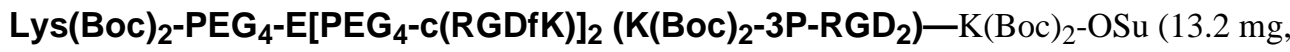
$30 \mu \mathrm{mol})$ and $3 \mathrm{P}-\mathrm{RGD}_{2}(18.3 \mathrm{mg}, 10 \mu \mathrm{mol})$ were dissolved in DMF $(2 \mathrm{~mL})$. After addition of excess DIEA $(50 \mu \mathrm{mol})$, the reaction mixture was stirred at room temperature for $5 \mathrm{~h}$. The product was separated using the same HPLC method for $\mathrm{K}(\mathrm{Boc})_{2}-\mathrm{RGD}_{2}$. The fractions at 15.5 min were collected. Lyophilization of collected fractions afforded $\mathrm{K}(\mathrm{Boc})_{2}-3 \mathrm{P}-\mathrm{RGD}_{2}$. The yield was $14.6 \mathrm{mg}(\sim 61 \%)$. ESI-MS: $\mathrm{m} / \mathrm{z}=2388.2$ for $[\mathrm{M}+\mathrm{H}]^{+}(\mathrm{M}=2387.28$ calcd. for $\left.\left[\mathrm{C}_{108} \mathrm{H}_{178} \mathrm{~N}_{24} \mathrm{O}_{36}\right]\right)$.

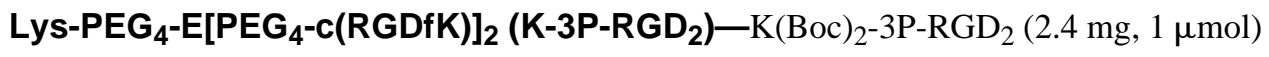
was dissolved in TFA $(1 \mathrm{~mL})$. After stirring at room temperature for 5-10 min, excess TFA was removed under reduced pressure. The residue was dissolved in $2 \mathrm{~mL}$ of water. The product was isolated by semi-prep HPLC (Method 1). The fractions at 12.5 min were collected and combined. Lyophilization of the combined fractions afforded the expected product K-3P-RGD 2 as its TFA salt. The yield was $1.7 \mathrm{mg}(\sim 78 \%)$. ESI-MS: $\mathrm{m} / \mathrm{z}=2188.5$ for $[\mathrm{M}+\mathrm{H}]^{+}\left(\mathrm{M}=2187.18\right.$ calcd. for $\left.\left[\mathrm{C}_{98} \mathrm{H}_{162} \mathrm{~N}_{24} \mathrm{O}_{32}\right]\right)$. 


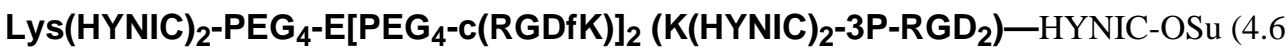
$\mathrm{mg}, 10 \mu \mathrm{mol})$ and $\mathrm{K}-3 \mathrm{P}-\mathrm{RGD}_{2}(2.2 \mathrm{mg}, 1.0 \mu \mathrm{mol})$ were dissolved in DMF $(1 \mathrm{~mL})$. After addition of excess DIEA $(50 \mu \mathrm{mol})$, the mixture was stirred at room temperature for 7 days. Upon addition of $2 \mathrm{~mL}$ water, the $\mathrm{pH}$ was adjusted to $4-4.5$ using TFA. The product was separated from the mixture using the same HPLC method for K(HYNIC $)_{2}-\mathrm{RGD}_{2}$. The fractions at $20.8 \mathrm{~min}$ were collected. Lyophilization of the collected fractions afforded $\mathrm{K}(\mathrm{HYNIC})_{2}-3 \mathrm{P}-\mathrm{RGD}_{2}$. The yield was $1.2 \mathrm{mg}(\sim 43 \%)$. ESI-MS: $\mathrm{m} / \mathrm{z}=2794.9$ for $[\mathrm{M}+\mathrm{H}]^{+}$ and 1398.0 for $[\mathrm{M}+\mathrm{H}]^{2+}\left(\mathrm{M}=2793.24\right.$ calcd. for $\left.\left[\mathrm{C}_{124} \mathrm{H}_{180} \mathrm{~N}_{30} \mathrm{O}_{40} \mathrm{~S}_{2}\right]\right)$.

\section{9mTc-Labeling}

To a clean $5 \mathrm{cc}$ vial were added the $\mathrm{K}$ (HYNIC) $)_{2}$-peptide conjugate solution $(25 \mu \mathrm{g}$ in $25 \mu \mathrm{L}$ water), $0.4 \mathrm{~mL}$ of $0.25 \mathrm{M}$ succinate buffer $(\mathrm{pH}=4.8)$, and $0.4 \mathrm{~mL}$ of tricine solution (20 $40 \mathrm{mg} / \mathrm{mL}$ in $0.25 \mathrm{M}$ succinate buffer). After addition of $0.5 \mathrm{~mL}$ of ${ }^{99} \mathrm{~m} \mathrm{TcO}_{4}{ }^{-}(740-1110$ $\mathrm{MBq}$ in saline) and $25 \mu \mathrm{L}$ of $\mathrm{SnCl}_{2}(1.0 \mathrm{mg} / \mathrm{mL}$ in $0.1 \mathrm{~N} \mathrm{HCl})$, the vial was heated at $100{ }^{\circ} \mathrm{C}$ for $20-30 \mathrm{~min}$ in a boiling water bath. The vial was then allowed to stand at room temperature for $\sim 5 \mathrm{~min}$. A sample of the resulting solution was analyzed by radio-HPLC (Method 2).

\section{Dose Preparation}

For biodistribution studies, ${ }^{99 \mathrm{~m}} \mathrm{Tc}$ radiotracers were purified by HPLC. Volatiles in the mobile phase were removed completely under vacuum $(<10 \mathrm{mmHg})$. Doses were prepared by dissolving the residual in saline to $\sim 1 \mathrm{MBq} / \mathrm{mL}$. For imaging studies, doses were prepared by dissolving the radiotracer in saline to $\sim 370 \mathrm{MBq} / \mathrm{mL}$. In the blocking experiment, $\mathrm{RGD}_{2}$ was dissolved in the dose solution to a concentration of $3.5 \mathrm{mg} / \mathrm{mL}$. The resulting solution was filtered with a $0.20 \mu \mathrm{m}$ Millex-LG filter before being injected into animals. Each animal was injected with $\sim 0.1 \mathrm{~mL}$ of the dose solution.

\section{In Vitro Whole-Cell Integrin $\alpha_{\mathrm{v}} \beta_{3}$ Binding Assay}

The integrin binding affinity of cyclic RGD peptides were assessed via a cellular competitive displacement assay using ${ }^{125}$ I-echistatin (Perkin Elmer, Branford, CT) as the radioligand. ${ }^{33}$ U87MG cell line was obtained from ATCC (American Type Culture Collection, Manassas, VA). Briefly, U87MG cells were grown in Eagle's Minimum Essential Medium (EMEM) supplemented with 10\% fetal bovine serum (FBS, ATCC), 100 $\mathrm{IU} / \mathrm{ml}$ penicillin and $100 \mu \mathrm{g} / \mathrm{ml}$ streptomycin (Invitrogen Co, Carlsbad, CA), at $37^{\circ} \mathrm{C}$ in humidified atmosphere containing $5 \% \mathrm{CO}_{2}$. Filter multiscreen DV plates (Millipore, Billerica, MA) were seeded with $1 \times 10^{5}$ glioma cells in binding buffer ( $20 \mathrm{mM}$ Tris, 150 $\mathrm{mM} \mathrm{NaCl}, 2 \mathrm{mM} \mathrm{CaCl}_{2}, 1 \mathrm{mM} \mathrm{MnCl}_{2}, 1 \mathrm{mM} \mathrm{MgCl}_{2}, 0.1 \%$ (wt/vol) bovine serum albumin; and $\mathrm{pH} 7.4)$ and ${ }^{125} \mathrm{I}$-echistatin $(0.7-1.0 \mathrm{kBq})$ in the presence of increasing amounts of RGD peptide, incubated for $2 \mathrm{~h}$ at room temperature. After removing the unbound ${ }^{125} \mathrm{I}$ echistatin, and being washed $3 \mathrm{x}$ with binding buffer, hydrophilic PVDF filters were collected. The radioactivity was determined using a Perkin Elmer Wizard - $1480 \gamma$-counter (Shelton, CT). All experiments were carried out twice in triplicates. $\mathrm{IC}_{50}$ values were calculated by fitting the experimental data with the nonlinear regression using GraphPad $\operatorname{Prism}^{\mathrm{TM}}$ (GraphPad Software, Inc., San Diego, CA), and reported as an average of six samples plus/minus the standard deviation. Comparison between two cyclic RGD peptides was made using the one-way ANOVA test. The level of significance was set at $p<0.05$.

\section{Animal Model}

Biodistribution and SPECT/CT imaging studies were performed in compliance with the NIH animal experimentation guidelines (Principles of Laboratory Animal Care, NIH Publication No. 86-23, revised 1985). The protocol was approved by the Purdue University Animal Care 
and Use Committee (PACUC). Female athymic $n u / n u$ mice were purchased from Harlan (Indianapolis, IN) at $4-5$ weeks of age, and were implanted with $5 \times 10^{6}$ U87MG cells in the shoulder flank. All procedures were performed in a laminar flow cabinet using aseptic techniques. Four weeks after inoculation, the tumor size was $0.1-0.5 \mathrm{~g}$, and animals were used for biodistribution and imaging studies.

\section{Biodistribution}

The tumor-bearing athymic nude mice $(20-25 \mathrm{~g})$ were randomly selected. Each animal was administered with $\sim 0.1 \mathrm{MBq}$ of the ${ }^{99 \mathrm{~m}} \mathrm{Tc}$ radiotracer by the tail-vein injection. The animals $(\mathrm{n}=4-6)$ were sacrificed by sodium pentobarbital overdose $(\sim 200 \mathrm{mg} / \mathrm{kg})$ at $60 \mathrm{~min}$ postinjection (p.i.). Blood was withdrawn from the heart. Tumors and normal organs (brain, eyes, heart, intestine, kidneys, liver, lungs, muscle and spleen) were harvested immediately after death, washed with saline, dried with absorbent paper, weighed, and counted to determine the radioactivity accumulation using a Perkin Elmer Wizard - $1480 \gamma$-counter (Shelton, CT). The organ uptake was calculated as the percentage of injected dose per gram of organ mass $(\% \mathrm{ID} / \mathrm{g})$. Biodistribution data and tumor-to-background (T/B) ratios are reported as an average plus/minus the standard deviation from four tumor-bearing mice. Comparison of different radiotracers was made using one-way ANOVA followed by pairwise Tukey's post-hoc test. The level of significance was set at $p<0.05$.

\section{SPECT/CT Imaging}

SPECT/CT images were obtained using a u-SPECT-II/CT scanner (Milabs, Utrecht, The Netherlands) equipped with a $0.6 \mathrm{~mm}$ multi-pinhole collimator. The glioma-bearing mouse was injected with $\sim 37 \mathrm{MBq}$ of 4 in $0.1 \mathrm{~mL}$ saline via the tail vein. At $60 \mathrm{~min}$ p.i., the animal was placed into a shielded chamber connected to an isoflurane anesthesia unit (Univentor, Zejtun, Malta). Anesthesia was induced using an air flow rate of $350 \mathrm{~mL} / \mathrm{min}$ and $~ 3.0 \%$ isoflurane. After induction of anesthesia, the animal was placed supine on the scanning bed. The air flow rate was then reduced to $\sim 250 \mathrm{~mL} / \mathrm{min}$ with $\sim 2.0 \%$ isoflurane. Rectangular scan in regions of the interest (ROIs) from both SPECT and CT were selected on the basis of orthogonal optical images provided by the integrated webcams. After SPECT acquisition (75 projections over 30 min per frame, 2 frames), the animal was then translated into the attached CT scanner and imaged using the 'normal' acquisition settings (2 degree intervals) at $45 \mathrm{kV}$ and $500 \mu \mathrm{A}$. After CT acquisition, the animal was allowed to recover in a leadshielded cage. SPECT reconstruction, data processing and quantification of organ uptake were performed according to the methods described in our previous reports. ${ }^{43,44}$ The reconstructed images were visualized as both orthogonal slices and maximum intensity projections.

\section{Metabolism}

Normal athymic nude mice $(\mathrm{n}=3)$ were used for metabolism study. Each animal was administered with $\sim 100 \mu \mathrm{Ci}$ of $\mathbf{4}$ via tail vein. Urine samples were collected at $30 \mathrm{~min}$ and 120 min p.i. by manual void, and were mixed with equal volume of $50 \%$ acetonitrile aqueous solution. The mixture was centrifuged at $8,000 \mathrm{rpm}$. The supernatant was collected and filtered with the $0.20 \mu \mathrm{m}$ syringe-driven Millex-LG filter unit to remove foreign particles. The filtrate was analyzed by radio-HPLC. Feces samples were collected at 120 min p.i. and suspended in $25 \%$ acetonitrile aqueous solution. The resulting mixture was vortexed for $\sim 5 \mathrm{~min}$. After centrifuging at $8,000 \mathrm{rpm}$, the supernatant was collected and filtered with the $0.20 \mu \mathrm{m}$ syringe-driven Millex-LG filter unit to remove foreign particles. The filtrate was analyzed by radio-HPLC. 


\section{RESULTS \\ HYNIC-Conjugate Synthesis}

Chart I shows the synthetic scheme for $\mathrm{K}(\mathrm{HYNIC})_{2}$-conjugated cyclic RGD peptide dimers. First, the peptide reacted with $\mathrm{K}(\mathrm{Boc})_{2}-\mathrm{OSu}$ in the presence of DIEA afforded $\mathrm{K}(\mathrm{Boc})_{2}-\mathrm{BM}$ $\left(\mathrm{BM}=\mathrm{RGD}_{2}, 3 \mathrm{G}-\mathrm{RGD}_{2}, 2 \mathrm{P}-\mathrm{RGD}_{2}\right.$ and $\left.3 \mathrm{P}-\mathrm{RGD}_{2}\right)$. Deprotection of Boc-protecting groups in neat TFA gave the intermediate: K-RGD $2, \mathrm{~K}-3 \mathrm{G}-\mathrm{RGD}_{2}, \mathrm{~K}-2 \mathrm{P}-\mathrm{RGD}_{2}$ and $\mathrm{K}-3 \mathrm{P}-\mathrm{RGD}_{2}$, respectively, which were then allowed to react with excess HYNIC-OSu in the presence of DIEA to afford the final product: $\mathrm{K}(\mathrm{HYNIC})_{2}-\mathrm{RGD}_{2}, \mathrm{~K}(\mathrm{HYNIC})_{2}-3 \mathrm{G}-\mathrm{RGD}_{2}$, $\mathrm{K}(\mathrm{HYNIC})_{2}-2 \mathrm{P}-\mathrm{RGD}_{2}$ and $\mathrm{K}(\mathrm{HYNIC})_{2}-3 \mathrm{P}-\mathrm{RGD}_{2}$, respectively. All new cyclic RGD peptide conjugates were purified by semi-prep HPLC (Method 1) and characterized by ESIMS. The mass spectral data were completely consistent with the proposed composition. Their HPLC purities were $>95 \%$ before being used for the integrin $\alpha_{v} \beta_{3}$ binding assay and ${ }^{99 \mathrm{~m}}$ Tc-labeling.

\section{Integrin $\alpha_{v} \beta_{3}$ Binding Affinity}

Figure 2 shows the displacement curves of ${ }^{125}$ I-echistatin bound to U87MG cells in the presence of cyclic RGD peptides. For comparison purpose, c(RGDfK) was also evaluated in the same assay. $\mathrm{IC}_{50}$ values were calculated to be $47 \pm 2,35 \pm 2,37 \pm 2,85 \pm 2$ and $422 \pm 15 \mathrm{nM}$ for $\mathrm{K}(\mathrm{HYNIC})_{2}-2 \mathrm{P}-\mathrm{RGD}_{2}, \mathrm{~K}(\mathrm{HYNIC})_{2}-3 \mathrm{P}-\mathrm{RGD}_{2}, \mathrm{~K}(\mathrm{HYNIC})_{2}-3 \mathrm{G}-\mathrm{RGD}_{2}, \mathrm{~K}(\mathrm{HYNIC})_{2}$ $\mathrm{RGD}_{2}$ and $\mathrm{c}(\mathrm{RGDyK})$, respectively. The integrin $\mathrm{a}_{\mathrm{v}} \beta_{3}$ binding affinity follows the order of $\mathrm{K}(\mathrm{HYNIC})_{2}-3 \mathrm{G}-\mathrm{RGD}_{2} \sim \mathrm{K}(\mathrm{HYNIC})_{2}-2 \mathrm{P}-\mathrm{RGD}_{2} \sim \mathrm{K}(\mathrm{HYNIC})_{2}-3 \mathrm{P}-\mathrm{RGD}_{2}>\mathrm{K}(\mathrm{HYNIC})_{2}-$ $\mathrm{RGD}_{2} \gg \mathrm{c}(\mathrm{RGDfK})$ (Figure 2), which was very similar to the trend reported for HYNIC and DOTA-conjugated cyclic RGD peptide dimers in our previous communications. ${ }^{33,40}$

\section{Radiochemistry}

Macrocyclic ${ }^{99 \mathrm{~m}} \mathrm{Tc}$ complexes $\mathbf{1}-\mathbf{4}$ were prepared (Chart I) from the reaction of respective

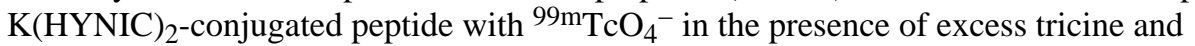
stannous chloride. ${ }^{99 \mathrm{~m}} \mathrm{Tc}-$ Labeling was completed by heating the reaction mixture at $100{ }^{\circ} \mathrm{C}$ for $10-20 \mathrm{~min}$. Complexes $1-4$ had high radiochemical purity (Table 1: RCP >95\%) and high specific activity $(\sim 150 \mathrm{GBq} / \mu \mathrm{mol})$ without chromatographic purification. They also had high solution stability in the kit matrix at room temperature (Figure SI1). Excess tricine $(10-50 \mathrm{mg} / \mathrm{vial})$ was required to prevent formation of [ ${ }^{99 \mathrm{~m}} \mathrm{Tc}$ ]colloid. If the tricine concentration was $<10 \mathrm{mg} / \mathrm{vial}$, [ ${ }^{99 \mathrm{~m}} \mathrm{Tc}$ ]colloid formation might become significant. If the tricine concentration was $>60 \mathrm{mg} / \mathrm{vial}$, the radiolabeling yield was also low $(<90 \%)$ for ${ }^{99 \mathrm{~m}} \mathrm{Tc}$ radiotracers. Since tricine has the buffering capacity at $\mathrm{pH}=4-5$, there was no need for extra buffering agent. We tried to replace tricine with $\mathrm{N}$-(2-hydroxyethyl)glycine and ethylenediamine-N, $\mathrm{N}^{\prime}$-diacetic acid, but the RCP for their ${ }^{99 \mathrm{~m}} \mathrm{Tc}$ complexes was low $(<70 \%)$. Tricine remains the best with respect to RCP of ${ }^{99 \mathrm{~m}} \mathrm{Tc}$ complexes.

\section{Isomerism}

Figure 3 shows radio-HPLC chromatograms of $\mathbf{1}-\mathbf{4}$. Due to the asymmetric nature of $\mathrm{K}(\mathrm{HYNIC})_{2}$ in bonding to Tc, there are several possible isomers (Figure 3: A - H). Isomers $\mathbf{A}-\mathbf{D}$ and $\mathbf{E}-\mathbf{H}$ are in distinguishable in aqueous solution since the proton can be on $\mathrm{N}$ or $\mathrm{O}$ atom. Both tricine and its Tc chelate are chiral once $\left[{ }^{99 \mathrm{~m}} \mathrm{Tc}\left(\mathrm{K}(\mathrm{HYNIC})_{2}-\mathrm{BM}\right)(\right.$ tricine $\left.)\right]$ is formed. The combination of $\mathbf{A}-\mathbf{H}$ with chiral centers in [ ${ }^{99 \mathrm{~m}} \mathrm{Tc}\left(\mathrm{K}(\mathrm{HYNIC})_{2}\right)($ tricine $)$ ] will result in many isomers. It was not surprising that more than two radiometric peaks (Figure 3: top) were observed in the radio-HPLC chromatograms of $\mathbf{1}$ and $\mathbf{2}$. Attempts to separate these peaks using various chromatographic conditions (different columns, flow rates and ionic strength) were unsuccessful. Complexes $\mathbf{3}$ and $\mathbf{4}$ always show one single radiometric peak in their radio-HPLC chromatograms, most likely due to the much larger size of the cyclic RGD 
peptide (>2,000 Daltons) than that of [ ${ }^{99 \mathrm{~m}} \mathrm{Tc}\left(\mathrm{K}(\mathrm{HYNIC}){ }_{2}\right)$ (tricine)] ( 670 Daltons). It is important to note that one radiometric peak doesn't necessarily mean only one isomer or one species.

We also prepared $\mathrm{K}(\mathrm{HYNIC})_{2}-\mathrm{RGD}_{2}$ as the unprotected free hydrazine (Figure 4: top). The purpose was to determine if the two hydrazone-protecting groups in $\mathrm{K}(\mathrm{HYNIC})_{2}-\mathrm{RGD}_{2}$ were removed during ${ }^{99 \mathrm{~m}} \mathrm{Tc}$-labeling. We found that the same macrocyclic ${ }^{99 \mathrm{~m}} \mathrm{Tc}$ complex was prepared from the free-hydrazine or hydrazone-protected $\mathrm{K}(\mathrm{HYNIC})_{2}-\mathrm{RGD}_{2}$, as evidenced by their almost identical radio-HPLC profiles (Figure 4: bottom) under identical chromatographic conditions. We believe that both hydrazone-protecting groups in $\mathrm{K}(\mathrm{HYNIC})_{2}$ were removed during ${ }^{99 \mathrm{~m}} \mathrm{Tc}$ chelation. If the hydrazone-protecting groups in $\mathrm{K}(\mathrm{HYNIC})_{2}-\mathrm{RGD}_{2}$ were not removed during ${ }^{99 \mathrm{~m}} \mathrm{Tc}$-labeling, macrocyclic ${ }^{99 \mathrm{~m}} \mathrm{Tc}$ complexes prepared from the hydrazone-protected $\mathrm{K}(\mathrm{HYNIC})_{2}-\mathrm{RGD}_{2}$ would have had completely different radio-HPLC profiles (retention times and patterns) from those from the freehydrazine.

\section{Biodistribution}

Table 1 lists the selected biodistribution data of $\mathbf{1}-\mathbf{5}$. Complex 5 was evaluated in the same model for comparison purposes. The 60-min data were used since the blood radioactivity was relatively low. Among the five radiotracers evaluated in this study, $\mathbf{1}$ had lowest tumor uptake $(3.78 \pm 0.81 \% \mathrm{ID} / \mathrm{g})$ and the poorest tumor/background ratios (Table 2). The tumor uptake of $\mathbf{2}-\mathbf{5}$ was comparable within the experimental errors, which was completely consistent with similar integrin $\alpha_{\mathrm{v}} \beta_{3}$ binding affinity of the corresponding cyclic RGD peptides (Figure 2). The uptake of $\mathbf{2}-\mathbf{4}$ in the kidneys, lungs and spleen was lower than that of 5 (Table 2). These data suggest that the targeting biomolecule has significant impact on the radiotracer uptake in both tumors and normal organs. Figure $5 A$ compares the 60-min biodistribution data of $\mathbf{4}-\mathbf{6}$. Biodistribution data for $\mathbf{6}$ were from our previous report. ${ }^{32} \mathrm{It}$ was quite obvious that replacing [ ${ }^{99 \mathrm{~m}} \mathrm{Tc}(\mathrm{HYNIC})($ tricine)(TPPTS)] with $\left[{ }^{99 \mathrm{~m}} \mathrm{Tc}\left(\mathrm{K}(\mathrm{HYNIC})_{2}\right)\right.$ (tricine)] had little impact on the radiotracer tumor uptake, but it significantly influenced the uptake of ${ }^{99 \mathrm{~m}} \mathrm{Tc}$ radiotracers in the intestines, kidneys, lungs and spleen. Since K(HYNIC) $)_{2}$ is structurally similar to HYNIC-K(NIC), we were not surprised that $\mathbf{4}$ and $\mathbf{6}$ shared very similar biodistribution properties in the tumor and normal organs (Figure 5A).

\section{Integrin $\alpha_{v} \beta_{3}$ Specificity}

Figure $5 B$ compares the organ uptake $(\% \mathrm{ID} / \mathrm{g})$ of 4 in the absence/presence of excess $\mathrm{RGD}_{2}$ at 60 min p.i. Co-injection of excess $\mathrm{RGD}_{2}$ significantly blocked its tumor uptake (1.81 \pm $0.56 \% \mathrm{ID} / \mathrm{g}$ with $\mathrm{RGD}_{2}$ vs $8.59 \pm 1.52 \% \mathrm{ID} / \mathrm{g}$ without $\mathrm{RGD}_{2}$ ). The uptake of 4 in the intestine was $10.30 \pm 5.01 \% \mathrm{ID} / \mathrm{g}$ without $\mathrm{RGD}_{2}$ and $4.41 \pm 2.07 \% \mathrm{ID} / \mathrm{g}$ in the presence of excess $\mathrm{RGD}_{2}$. These data suggest that intestine is integrin $a_{v} \beta_{3}$-positive. The blood radioactivity level was higher in animals administered with excess $\mathrm{RGD}_{2}$ than that without excess $R_{G D}$, probably due to the reduced uptake in the integrin $a_{v} \beta_{3}$-positive organs. Similar results were reported for other integrin $\alpha_{\mathrm{v}} \beta_{3}$-targeted radiotracers. ${ }^{32-40}$

\section{SPECT/CT Imaging}

We obtained SPECT/CT images of an athymic nude mouse bearing U87MG glioma xenografts. Figure 6 shows the 3D and transverse views of SPECT/CT image of a gliomabearing mouse. The tumor $\left(\sim 0.2 \mathrm{~cm}^{3}\right)$ was clearly visualized by SPECT/CT with excellent contrast. The tumor uptake was $\sim 7.5 \% \mathrm{ID} / \mathrm{cm}^{3}$ on the basis of SPECT quantification. The tumor/muscle ratio was $>10: 1$. The uptake of $\mathbf{4}$ in the kidneys, liver, lungs, and muscle was relatively low. Its high intestine uptake was supported by the biodistribution data (Table 2). 
The SPECT/CT data clearly showed that $\mathbf{4}$ is an excellent radiotracer for noninvasive imaging of U87MG gliomas with high integrin $a_{v} \beta_{3}$ expression on both tumor cells and the tumor neovasculature. ${ }^{32,39}$

\section{Metabolism}

We examined the metabolic stability of 4 using normal mice $(n=3)$. The radioactivity recovery from the urine and feces samples was $>95 \%$. Figure 7 shows radio-HPLC chromatograms of $\mathbf{4}$ in saline before injection (top) and in urine at $30 \mathrm{~min}$ p.i. (middle) and 120 min p.i. (bottom). There was very little metabolism in the urine samples at 30 and 120 min p.i. Attempts were made to isolate sufficient radioactivity from feces for HPLC; but they were unsuccessful because $>90 \%$ of collected radioactivity was found in the urine. We believe that $\mathbf{4}$ had a high metabolic stability during its excretion in athymic nude mice. Its metabolic stability was similar to that reported for $6,{ }^{32}$ most likely due to their structural similarity (Figure 1: B and C).

\section{DISCUSSION}

In this study, we evaluated $\mathrm{K}(\mathrm{HYNIC})_{2}$ as a BFC for ${ }^{99 \mathrm{~m}} \mathrm{Tc}$-labeling of cyclic RGD peptides and compared three chelating systems (Figure 1: A - C) with respect to the biodistribution of their ${ }^{99 \mathrm{~m}} \mathrm{Tc}$ radiotracers. We found that $\mathrm{K}(\mathrm{HYNIC})_{2}$-conjugated RGD peptides had the integrin $a_{v} \beta_{3}$ binding affinity comparable to that of their HYNIC analogs. ${ }^{34,35}$ A major advantage of $\mathrm{K}(\mathrm{HYNIC})_{2}$ over the ternary ligand system (HYNIC, tricine and TPPTS) is the use of $\mathrm{SnCl}_{2}$ as a reducing agent. This is very important for ${ }^{99 \mathrm{~m}} \mathrm{Tc}$-labeling of small biomolecules with one or more disulfide linkages, which are vital to maintain their structural rigidity and receptor binding affinity. The use of TPPTS at elevated temperatures may destroy the S-S disulfide bonds. The disadvantage of $\mathrm{K}(\mathrm{HYNIC})_{2}$ is that $\left[{ }^{99 \mathrm{~m}} \mathrm{Tc}\left(\mathrm{K}(\mathrm{HYNIC})_{2}\right)\right.$ (tricine)] has more than 2 isomers, which were not separable under chromatographic conditions used in this study. Similar results were also obtained for macrocyclic complexes $\left[{ }^{99 \mathrm{~m}} \mathrm{Tc}(\mathrm{HYNIC}-\mathrm{K}(\mathrm{NIC})-\mathrm{BM})(\right.$ tricine $\left.)\right] .{ }^{31}$ Future research will be directed towards developing symmetrical bis-HYNIC analogs that form macrocyclic ${ }^{99 \mathrm{~m}} \mathrm{Tc}$ chelates with two or less isomers.

[99m $\mathrm{Tc}\left(\mathrm{K}(\mathrm{HYNIC})_{2}\right)$ (tricine)] (Molecular Weight: $~ 670$ Daltons) has an overall neutral charge, and is smaller than [ ${ }^{99 \mathrm{~m}} \mathrm{Tc}(\mathrm{HYNIC})($ tricine)(TPPTS)] (Molecular Weight: 970 Daltons). However, replacing [99m $\mathrm{Tc}(\mathrm{HYNIC})\left(\right.$ tricine)(TPPTS)] with [ ${ }^{99 \mathrm{~m}} \mathrm{Tc}\left(\mathrm{K}(\mathrm{HYNIC})_{2}\right)$ (tricine)] had little impact on the tumor uptake of ${ }^{99 \mathrm{~m}} \mathrm{Tc}$ radiotracers (Figure $5 A$ ), suggesting that changing ${ }^{99 \mathrm{~m}} \mathrm{Tc}$ chelates had no adverse effect on their integrin $\mathrm{a}_{\mathrm{v}} \beta_{3}$ binding affinity. We also found that $\mathbf{4}$ had significantly less uptake than $\mathbf{5}$ in kidneys, lungs and spleen (Figure 5A: $\mathrm{p}<0.05$ ), strongly suggesting that ${ }^{99 \mathrm{~m}} \mathrm{Tc}$ chelates had significant impact on biodistribution of their ${ }^{99 \mathrm{~m}} \mathrm{Tc}$ radiotracers. The metabolic stability of $\mathbf{4}$ was similar to that of 5 and $\mathbf{6}^{32,33}$ Our previous studies showed that the metabolic instability of $\mathbf{6}$ during hepatobiliary excretion had little impact on its \%ID/g tumor uptake and the linear relationship between the tumor uptake of $\mathbf{6}$ and integrin $\alpha_{v} \beta_{3}$ expression levels. ${ }^{33}$

Since the same macrocyclic ${ }^{99} \mathrm{~m}$ Tc complex was prepared from K(HYNIC) $)_{2}-\mathrm{RGD}_{2}$ in its unprotected and hydrazone-protected forms, we believe that the two hydrazone-protecting groups in $\mathrm{K}(\mathrm{HYNIC})_{2}$ were removed during ${ }^{99 \mathrm{~m}} \mathrm{Tc}$-labeling. Thus, $\left[{ }^{99 \mathrm{~m}} \mathrm{Tc}\left(\mathrm{K}(\mathrm{HYNIC})_{2}\right)\right.$ (tricine)] (Figure 1C) has a structure similar to that of [ ${ }^{99 \mathrm{~m}} \mathrm{Tc}(\mathrm{HYNIC}-\mathrm{K}(\mathrm{NIC})$ )(tricine)] (Figure $1 B$ ), the composition of which was confirmed by LC-MS data. ${ }^{31}$ However, it remains unclear about the exact structure of $\left[{ }^{99 \mathrm{~m}} \mathrm{Tc}\left(\mathrm{K}(\mathrm{HYNIC})_{2}\right)\right.$ (tricine)]. It is quite possible that one HYNIC is monodentate and the other is bidentate in $\left[{ }^{99 \mathrm{~m}} \mathrm{Tc}\left(\mathrm{K}(\mathrm{HYNIC})_{2}\right)\right.$ (tricine)] (Figure 1C). Anionic monodentate pyridyldiazenido (Figure 3: A and E), neutral bidentate pyridyldiazene (Figure 3: B and F), anionic bidentate pyridyldiazenido (Figure 3: 
$\mathrm{C}$ and $\mathrm{G}$ ), and monodentate pyridiniumdiazenido (Figure 3: $\mathrm{D}$ and $\mathrm{H}$ ) have been found in many $\mathrm{Tc}(\mathrm{III})$ and $\mathrm{Re}(\mathrm{III})$ complexes, ${ }^{45-51}$ such as $\left[\mathrm{TcCl}_{3}\left(\mathrm{HN}=\mathrm{NC}_{5} \mathrm{H}_{4} \mathrm{~N}\right)\left(\mathrm{N}=\mathrm{NC}_{5} \mathrm{H}_{4} \mathrm{NH}\right)\right]$ and $\left.\left[\mathrm{ReCl}_{2}\right)\left(\mathrm{PPh}_{3}\right)\left(\mathrm{N}=\mathrm{NC}_{5} \mathrm{H}_{4} \mathrm{~N}\right)\left(\mathrm{HN}=\mathrm{NC}_{5} \mathrm{H}_{4} \mathrm{~N}\right)\right]$, both of which were characterized by $\mathrm{X}$ ray crystallography. ${ }^{46,47}$ Because of bidentate HYNIC, the backbone rotations in [99m $\mathrm{Tc}\left(\mathrm{K}(\mathrm{HYNIC})_{2}\right)$ (tricine)] will be limited, preventing interconversion of conformational isomers. It is not surprising that $>2$ radiometric peaks were observed in HPLC chromatograms of $\mathbf{1}$ and $\mathbf{2}$ (Figure 3: A and B). However, in the absence of solid-state structure and NMR studies, this explanation remains largely a speculation. Structure studies of macrocyclic ${ }^{99} \mathrm{Tc}$ complexes will help us understand the coordination chemistry of bisHYNIC chelators in their macrocyclic ${ }^{99} \mathrm{~m}$ Tc complexes.

\section{CONCLUSION}

This study show that $\mathrm{K}(\mathrm{HYNIC})_{2}$ is useful as a BFC for ${ }^{99 \mathrm{~m}} \mathrm{Tc}$-labeling of small biomolecules, such as cyclic RGD peptides. Replacing [99m $\mathrm{Tc}(\mathrm{HYNIC})($ tricine)(TPPTS)] with $\left[{ }^{99 \mathrm{~m}} \mathrm{Tc}\left(\mathrm{K}(\mathrm{HYNIC})_{2}\right)\right.$ (tricine)] had little impact on the tumor uptake of radiotracers; but it significantly affected the radiotracer uptake in kidneys, lungs and spleen. Since $\left[{ }^{99 \mathrm{~m}} \mathrm{Tc}\left(\mathrm{K}(\mathrm{HYNIC})_{2}\right)\right.$ (tricine)] exists in solution as several isomers, future research should be directed towards developing symmetrical bis-HYNIC analogs that form macrocyclic ${ }^{99 \mathrm{~m}} \mathrm{Tc}$ complexes with two or less isomers.

\section{Supplementary Material}

Refer to Web version on PubMed Central for supplementary material.

\section{Acknowledgments}

This work was supported by Purdue University, the Indiana Clinical and Translational Sciences Institute funded, in part, by grant Number TR000006 (Clinical and Translational Award) from the National Institutes of Health, National Center for advancing Translational Science, R01 CA115883 (S.L.) from the National Cancer Institute, and KG111333 (Y.Z. and S.L.) from the Susan G. Komen Breast Cancer Foundation.

\section{References}

1. Abrams MJ, Juweid M, tenKate CI, Schwartz DA, Hauser MM, Gaul FE, Fuccello AJ, Rubin RH, Strauss HW, Fischman AJ. Technetium-99m-human polyclonal IgG radiolabeled via the hydrazino nicotinamide derivative for imaging focal sites of infection in rats. J Nucl Med. 1990; 31:20222028. [PubMed: 2266401]

2. Schwartz DA, Abrams MJ, Hauser MM, Gaul FE, Larsen SK, Rauh D, Zubieta J. Preparation of hydrazino-modified proteins and their use for the synthesis of ${ }^{99 \mathrm{~m}} \mathrm{Tc}$-protein conjugates. Bioconjugate Chem. 1991; 2:333-336.

3. Ultee ME, Bridger GJ, Abrams MJ, Longley CB, Burton CA, Larsen S, Henson GW, Padmanabhan S, Gaul FE, Schwartz DA. Tumor imaging with technetium-99m-labeled hydrazinonicotinamideFab' conjugates. J Nucl Med. 1997; 38:133-138. [PubMed: 8998167]

4. Bridger GJ, Abrams MJ, Padmanabhan S, Gaul FE, Larsen S, Henson GW, Schwartz DA, Burton CA, Ultee ME. A comparison of cleavable and noncleavable hydrazinopyridine linkers for the 99m Tc-labeling of Fab' monoclonal antibody fragments. Bioconjugate Chem. 1996; 7:255-264.

5. Babich JW, Solomon H, Pike MC, Kroon D, Graham W, Abrams MJ, Tompkins RG, Rubin RH, Fischman AJ. Technetium-99m labeled hydrazino nicotinamide derivatized chemotactic peptide analogs for imaging focal sites of bacterial infection. J Nucl Med. 1993; 34:1967-1974.

6. Babich JW, Fischman AJ. Effect of "co-ligand" on the biodistribution of $99 \mathrm{~m}$ Tc-labeled hydrazino nicotinic acid derivatized chemotactic peptides. Nucl Med Biol. 1995; 22:25-30. [PubMed: 7735166] 
7. Babich JW, Graham W, Barrow SA, Fischman AJ. Comparision of the infection imaging properties of a ${ }^{99} \mathrm{~m}$ Tc labeled chemotactic peptide with ${ }^{111}$ In IgG. Nucl Med Biol. 1995; 22:643-648.

[PubMed: 7581175]

8. Decristoforo C, Mather SJ. ${ }^{99} \mathrm{~m}$ Tc-labeled peptide-HYNIC conjugates: effect of lipophilicity and stability on biodistribution. Nucl Med Biol. 1999; 26:389-396. [PubMed: 10382842]

9. Decristoforo C, Mather SJ. Preparation, ${ }^{99} \mathrm{~m}$ Tc-labeling, and in vitro characterization of HYNIC and $\mathrm{N}_{3} \mathrm{~S}$ modified RC-160 and [Tyr ${ }^{3}$ ]Octreotide. Bioconjugate Chem. 1999; 10:431-438.

10. Decristoforo C, Mather SJ. Technetium-99m somatostatin analogues: effect of labeling methods and peptide sequence. Eur J Nucl Med. 1999; 26:869-876. [PubMed: 10436200]

11. Decristoforo C, Melendez L, Sosabowski JK, Mather SJ. ${ }^{99 m} \mathrm{Tc}-\mathrm{HYNIC}-\left[\mathrm{Tyr}^{3}\right]$-octreotide for imaging somatostatin-receptor-positive tumors: preclinical evaluation and comparison with ${ }^{111} \mathrm{In}$ Octreotide. J Nucl Med. 2000; 41:1114-1119. [PubMed: 10855644]

12. Bangard M, Béhé M, Guhlke S, Otte R, Bender H, Maecke HR, Birsack HJ. Detection of somatostatin receptor-positive tumours using the new ${ }^{99 \mathrm{~m}}$ Tc-tricine-HYNIC-D-Phe ${ }^{1}-\mathrm{Tyr}^{3}$ octreotide: first results in patients and comparison with ${ }^{111} \mathrm{In}$-DTPA-D-Phe ${ }^{1}-\mathrm{Tyr}^{3}$-octreotide. Eur J Nucl Med. 2000; 27:628-637. [PubMed: 10901448]

13. Decristoforo C, Mather SJ, Cholewinski W, Donnemiller E, Riccabona G, Moncayo R. ${ }^{99 \mathrm{~m}} \mathrm{Tc}$ EDDA/HYNIC-TOC: a new ${ }^{99 \mathrm{~m}} \mathrm{Tc}$-labeled radiopharmaceutical for imaging somatostatin receptor-positive tumors: first clinical results and intra-patient comparison with ${ }^{111}$ In-labeled octreotide derivatives. Eur J Nucl Med. 2000; 27:1318-1325. [PubMed: 11007513]

14. Laverman P, Dams EThM, Oyen WJG, Storm G, Koenders EB, Prevost R, van der Meer JWM, Corstens FHM, Boerman OC. A novel method to label liposomes with ${ }^{99 \mathrm{~m}} \mathrm{Tc}$ by the hydrazine nicotinyl derivative. J Nucl Med. 1999; 40:192-197. [PubMed: 9935076]

15. Zhang YM, Liu N, Zhu ZH, Rusckowski M, Hnatowich DJ. Influence of different chelators (HYNIC, MAG $_{3}$ and DTPA) on tumor cell accumulation and mouse biodistribution of technetium-99m labeled antisense DNA. Eur J Nucl Med. 2000; 27:1700-1707. [PubMed: 11105827]

16. Hnatowich DJ, Winnard P Jr, Virzi F, Santo T, Smith CL, Cantor CR, Rusckowski M. Technetium-99m labeling of DNA oligonucleotides. J Nucl Med. 1995; 36:2306-2314. [PubMed: 8523124]

17. Guo W, Hinkle GH, Lee RJ. ${ }^{99} \mathrm{~m}_{\text {Tc-HYNIC-folate: a novel receptor-based targeted }}$ radiopharmaceutical for tumor imaging. J Nucl Med. 1999; 40:1563-1569. [PubMed: 10492380]

18. Ono M, Arano Y, Mukai T, Uehara T, Fujioka Y, Ogawa K, Namba S, Nakayama M, Saga T, Konishi J, Horiuchi K, Yokoyama A, Saji H. Plasma protein binding of ${ }^{99} \mathrm{~m}$ Tc-labeled hydrazine nicotinamide derivatized polypeptides and peptides. Nucl Med Biol. 2001; 28:155-164. [PubMed: 11295426]

19. Edwards DS, Liu S, Ziegler MC, Harris AR, Crocker AC, Heminway SJ, Barrett JA, Bridger GJ, Abrams MJ, Higgins JD. RP463: A stabilized technetium-99m complex of a hydrazinonicotinamide conjugated chemotactic peptide for infection imaging. Bioconjugate Chem. 1999; 10:884-891.

20. Brouwers AH, Laverman P, Boerman OC, Oyen WJG, Barrett JA, Harris TD, Edwards DS, Corstens FHM. A ${ }^{99}$ Tc-labeled leukotriene B4 receptor antagonist for scintigraphic detection of infection in rabbits. Nucl Med Commun. 2000; 21:1043-1050. [PubMed: 11192710]

21. Edwards DS, Liu S, Barrett JA, Harris AR, Looby RJ, Ziegler MC, Heminway SJ, Carroll TR. A new and versatile ternary ligand system for technetium radiopharmaceuticals: water soluble phosphines and tricine as coligands in labeling a hydrazino nicotinamide-modified cyclic glycoprotein IIb/IIIa receptor antagonist with ${ }^{99 m} \mathrm{Tc}$. Bioconjugate Chem. 1997; 8:146-154.

22. Liu S, Edwards DS, Ziegler MC, Harris AR, Hemingway SJ, Barrett JA. ${ }^{99 \mathrm{~m}}$ Tc-Labeling of a hydrazinonictotinamide-conjugated vitronectin receptor antagonist. Bioconjugate Chem. 2001; 12:624-629.

23. Liu S, Hsieh WY, Kim YS, Mohammed SI. Effect of coligands on biodistribution characteristics of ternary ligand $99 \mathrm{~m}$ Tc complexes of a HYNIC-conjugated cyclic RGDfK dimer. Bioconjugate Chem. 2005; 16:1580-1588. 
24. Liu S, Hsieh WY, Jiang Y, Kim YS, Sreerama SG, Chen X, Jia B, Wang F. Evaluation of a ${ }^{99 m}$ Tclabeled cyclic RGD tetramer for noninvasive imaging integrin $a_{v} \beta_{3}$-positive breast cancer. Bioconjugate Chem. 2007; 18:438-446.

25. Liu S, Kim YS, Hsieh WY, Sreerama SG. Coligand effects on solution stability, biodistribution and metabolism of ${ }^{99 m}$ Tc-labeled cyclic RGDfK tetramer. Nucl Med Biol. 2008; 35:111-121. [PubMed: 18158950]

26. Liu S, Edwards DS, Harris AR, Heminway SJ, Barrett JA. Technetium complexes of a hydrazinonicotinamide-conjugated cyclic peptide and 2-hydrazinopyridine: Synthesis and characterization. Inorg Chem. 1999; 38:1326-1335. [PubMed: 11670921]

27. Liu S, Ziegler MC, Edwards DS. Radio-LC-MS for the characterization of ${ }^{99 \mathrm{~m}} \mathrm{Tc}$-labeled bioconjugates. Bioconjugate Chem. 2000; 11:113-117.

28. Liu S, Edwards DS. ${ }^{99}$ Tc-labeled small peptides as diagnostic radiopharmaceuticals. Chem Rev. 1999; 99:2235-2268. [PubMed: 11749481]

29. Liu S. 6-Hydrazinonicotinamide derivatives as bifunctional coupling agents for ${ }^{99} \mathrm{~m}$ Tc-labeling of small biomolecules. Top Curr Chem. 2005; 252:117-153.

30. Meszaros LK, Dose A, Biagini SCG, Blower PJ. Hydrazinonicotinic acid (HYNIC) - coordination chemistry and applications in radiopharmaceutical chemistry. Inorg Chim Acta. 2010; 363:1059_ 1069.

31. Purohit A, Liu S, Casebier D, Haber SB, Edwards DS. Pyridine-containing HYNIC-derivatives as potential bifunctional chelators for ${ }^{99 \mathrm{~m}}$ Tc-labeling of small biomolecules. Bioconjugate Chem. 2004; 15:728-737.

32. Zhou Y, Kim YS, Lu X, Liu S. Evaluation of ${ }^{99 m}$ Tc-labeled cyclic RGD dimers: impact of cyclic RGD peptides and ${ }^{99} \mathrm{~m}$ Tc chelates on biological properties. Bioconjugate Chem. 2012; 23:586595.

33. Wang L, Kim YS, Shi J, Zhai S, Jia B, Liu Z, Zhao H, Wang F, Chen X, Liu S. Improving tumor

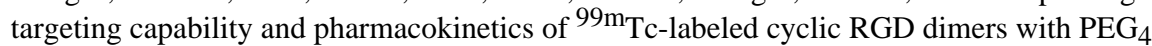
linkers. Mol Pharm. 2009; 6:231-245. [PubMed: 19067525]

34. Shi J, Wang L, Kim YS, Zhai S, Liu Z, Chen X, Liu S. Improving tumor uptake and excretion kinetics of ${ }^{99} \mathrm{~m}$ Tc-labeled cyclic Arginine-Glycine-Aspartic (RGD) dimers with triglycine linkers. J Med Chem. 2008; 51:7980-7990. [PubMed: 19049428]

35. Shi J, Wang L, Kim YS, Jia B, Zhao H, Wang F, Liu S. ${ }^{99} \mathrm{~m}_{\mathrm{TcO}}\left(\mathrm{MAG}_{2}-3 \mathrm{G}_{3}\right.$-dimer): A new integrin $a_{v} \beta_{3}$-targeted radiotracer with high tumor uptake and favorable pharmacokinetics. Eur $J$ Nucl Med Mol Imaging. 2009; 36:1874-1884. [PubMed: 19484236]

36. Shi J, Wang L, Kim YS, Zhai S, Liu Z, Chen X, Liu S. Improving tumor uptake and pharmacokinetics of ${ }^{64} \mathrm{Cu}$-labeled cyclic RGD dimers with $\mathrm{Gly}_{3}$ and $\mathrm{PEG}_{4}$ linkers. Bioconjugate Chem. 2009; 20:750-759.

37. Shi J, Wang L, Kim YS, Chakraborty S, Jia B, Wang F, Liu S. 2-Mercaptoacetylglycylglycyl $\left(\mathrm{MAG}_{2}\right)$ as a bifunctional chelator for ${ }^{99 \mathrm{~m}} \mathrm{Tc}$-labeling of cyclic RGD dimers: effects of technetium chelate on tumor uptake and pharmacokinetics. Bioconjugate Chem. 2009; 20:1559-1568.

38. Chakraborty S, Liu S, Kim YS, Shi J, Zhou Y, Wang F. Evaluation of ${ }^{111}$ In-labeled cyclic RGD peptides: tetrameric not tetravalent. Bioconjugate Chem. 2011; 21:969-978.

39. Zhou Y, Kim YS, Chakraborty S, Shi J, Gao H, Liu S. ${ }^{99}$ Tc-Labeled cyclic RGD peptides for noninvasive monitoring of tumor integrin $\alpha_{v} \beta_{3}$ expression. Mol Imaging. 2011; 10:386-397. [PubMed: 21521559]

40. Shi J, Zhou Y, Chakraborty S, Kim YS, Jia B, Wang F, Liu S. Evaluation of ${ }^{111}$ In-labeled cyclic RGD peptides: effects of peptide and $\mathrm{PEG}_{4}$ multiplicity on their tumor uptake, excretion kinetics and metabolic stability. Theranostics. 2011; 1:322-340. [PubMed: 21850213]

41. Shi J, Jia B, Kim YS, Chakraborty S, Zhou Y, Wang F, Liu S. Impact of bifunctional chelators on biological properties of ${ }^{111}$ In-labeled cyclic peptide RGD dimers. Amino Acids. 2011; 41:10591070. [PubMed: 20052508]

42. Harris TD, Sworin M, Willianms N, Rajopadhye M, Damphousse PR, Glowacka D, Poirier MJ, Yu $\mathrm{K}$. Synthesis of stable hydrazones of a hydrazinonicotinyl-modified peptide for the preparation of ${ }^{99} \mathrm{~m}$ Tc-labeled radiopharmaceuticals. Bioconjugate Chem. 1998; 10:808-814. 
43. Shao G, Zhou Y, Liu S. Monitoring glioma growth and tumor necrosis with u-SPECT-II/ CT for by targeting integrin $a_{\mathrm{v}} \beta_{3}$. Mol Imaging. in press.

44. Zhou Y, Shao G, Wang F, Liu S. Imaging breast cancer lung metastasis by u-SPECT-II/CT with an integrin $a_{v} \beta_{3}$-targeted radiotracer ${ }^{99}{ }^{\mathrm{T}} \mathrm{Tc}-3 \mathrm{P}-\mathrm{RGD}_{2}$. Theranostics. 2012; 2:577-587. [PubMed: 22737193]

45. Babich JW, Coco WG, Barrow SA, Fischman AJ, Femia FJ, Zibieta J. ${ }^{99}{ }^{9}$ Tc-labeled chemotactic peptides: influence of coligands on distribution of molecular species and infection imaging properties. Synthesis and structural characterization of model complexes with the $\{\operatorname{Re}(\eta 2-$ $\left.\left.\mathrm{HNNC}_{5} \mathrm{H}_{4} \mathrm{~N}\right)\left(\eta 1-\mathrm{HNNC}_{5} \mathrm{H}_{4} \mathrm{~N}\right)\right\}$ core. Inorg Chim Acta. 2000; 309:123-136.

46. Nicholson T, Cook J, Davison A, Rose DJ, Maresca KP, Zubieta JA, Jones AJ. The synthesis and characterization of $\left[\mathrm{MCl}_{3}\left(\mathrm{~N}=\mathrm{NC}_{5} \mathrm{H}_{4} \mathrm{NH}\right)\left(\mathrm{HN}=\mathrm{NC}_{5} \mathrm{H}_{4} \mathrm{~N}\right)\right]$ from $\left[\mathrm{MO}_{4}\right]^{-}$(where $\mathrm{M}=\mathrm{Re}, \mathrm{Tc}$ ) organodiazenido, organodiazene-chelate complexes. The X-ray structure of $\left[\mathrm{ReCl}_{3}\left(\mathrm{~N}_{=} \mathrm{NC}_{5} \mathrm{H}_{4} \mathrm{NH}\right)\right.$ $\left(\mathrm{HN}=\mathrm{NC}_{5} \mathrm{H}_{4} \mathrm{~N}\right)$ ]. Inorg Chim Acta. 1996; 252:421-426.

47. Nicholson T, Cook J, Davison A, Rose DJ, Maresca KP, Zubieta JA, Jones AJ. The synthesis, characterization and $\mathrm{X}$-ray crystal structure of the rhenium organodiazenido, organodiazene complex of $\left[\mathrm{ReCl}_{2}\left(\mathrm{PPh}_{3}\right)\left(\mathrm{N}=\mathrm{NC}_{5} \mathrm{H}_{4} \mathrm{~N}\right)\left(\mathrm{HN}=\mathrm{NC}_{5} \mathrm{H}_{4} \mathrm{~N}\right)\right]$. Inorg Chim Acta. 1996; 252:427-430.

48. Archer CM, Dilworth JR, Jobanputra P, Thompson RM, McPartlin M, Povey DC, Smith GW, Kelly JD. Development of new technetium cores containing technetium-nitrogen multiple bonds. Synthesis and characterization of some diazenido-, hydrazido- and imido-complexes of technetium. Polyhedron. 1990; 9:1497-1502.

49. Dilworth JR, Jobanputra P, Thompson RM, Archer CM, Povey DC, Kelly JD, Hiller W. Crystal structure of a diazenido-dithiocarbamate complex of technetium, $\left[\mathrm{Tc}\left(\mathrm{NNC}_{6} \mathrm{H}_{4} \mathrm{Cl}\right)\right.$ $\left.\left(\left(\mathrm{CH}_{3}\right)_{2} \mathrm{NCS}_{2}\right)_{2}\left(\mathrm{PPh}_{3}\right)\right]$. Z Naturforsch. 1992; 46:449-452.

50. Archer CM, Dilworth JR, Jobanputra P, Thompson RM, McPartin M, Hiller W. Technetium diazenido complexes. Part 1. Synthesis and structures of [TcCl( $\left.\left(\mathrm{NNC}_{6} \mathrm{H}_{4} \mathrm{Cl}-4\right)_{2}\left(\mathrm{PPh}_{3}\right)_{2}\right]$ and [TcCl(NNPh) $\left.\left(\mathrm{Ph}_{2} \mathrm{PCH}_{2} \mathrm{CH}_{2} \mathrm{PPh}_{2}\right)_{2}\right]\left[\mathrm{PF}_{6}\right] . \mathrm{H}_{2} \mathrm{O}$. J Chem Soc, Dalton Trans. 1993:897-904.

51. Dilworth JR, Jobanputra P, Thompson RM, Povey DC, Archer CM, Kelly JD. Technetium diazenido complexes. Part 2. Substitution chemistry of structures of $\left[\mathrm{TcCl}\left(\mathrm{NNC}_{6} \mathrm{H}_{4} \mathrm{Cl}-4\right)_{2}\left(\mathrm{PPh}_{3}\right)_{2}\right]$ and the synthesis of technetium diazenido-complexes directly from [NH $4\left[\mathrm{NcO}_{4}\right]$. J Chem Soc, Dalton Trans. 1994:1251-1256. 


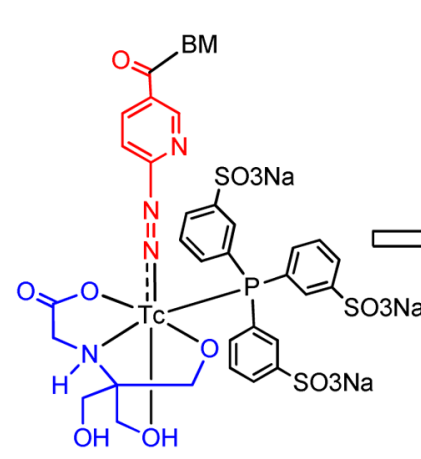

A

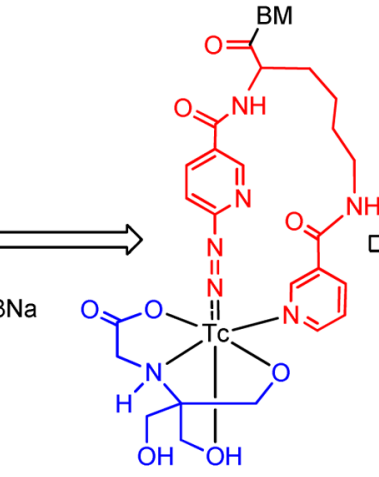

$B$

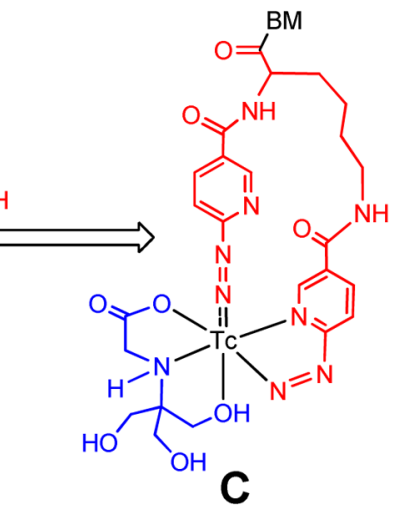

$\mathrm{BM}=$ Biomolecule $\left(R \mathrm{RD}_{2}, 3 \mathrm{G}-\mathrm{RGD} \mathrm{D}_{2}, 2 \mathrm{P}-\mathrm{RG} \mathrm{D}_{2}\right.$ and $\left.3 \mathrm{P}-\mathrm{RGD}_{2}\right)$

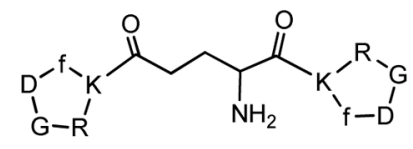

$\mathrm{RGD}_{2}$

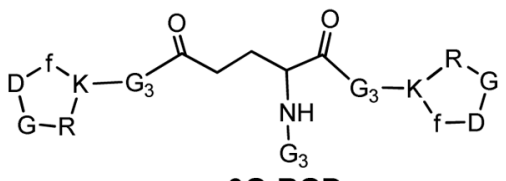

$3 G-R G D_{2}$

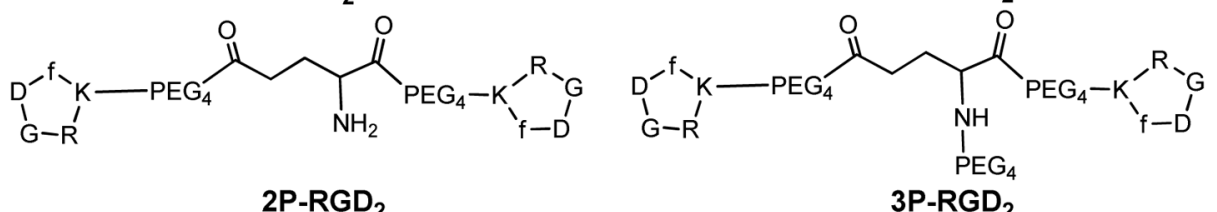<smiles>CC(=O)CNC(=O)CNC(=O)CN</smiles>

1: $\left[{ }^{99 m} \mathrm{Tc}\left((\mathrm{HYNIC})_{2} \mathrm{~K}-\mathrm{RGD}_{2}\right)\right.$ (tricine)]

2: [ ${ }^{99 \mathrm{~m}} \mathrm{Tc}\left((\mathrm{HYNIC})_{2} \mathrm{~K}-3 \mathrm{G}-\mathrm{RGD}_{2}\right)$ (tricine)]

3: [ ${ }^{99 \mathrm{~m}} \mathrm{Tc}\left((\mathrm{HYNIC})_{2} \mathrm{~K}-2 \mathrm{P}-\mathrm{RGD}_{2}\right)$ (tricine)]

4: $\left[{ }^{99 m} \mathrm{Tc}\left((\mathrm{HYNIC})_{2} \mathrm{~K}-3 \mathrm{P}-\mathrm{RGD}_{2}\right)(\right.$ tricine $\left.)\right]$

5: [ ${ }^{99 \mathrm{~m}} \mathrm{Tc}\left(\mathrm{HYNIC}-3 \mathrm{P}-\mathrm{RGD}_{2}\right)$ (tricine)(TPPTS)]

6: [ ${ }^{99 m} \mathrm{Tc}\left(\mathrm{HYNIC}-\mathrm{K}(\mathrm{NIC})-3 \mathrm{P}-\mathrm{RGD}_{2}\right)($ tricine $\left.)\right]$<smiles>CC(=O)CCOCCOCCOCCOCCN</smiles><smiles></smiles>

Figure 1.

Structure of cyclic RGD peptide dimers and their ${ }^{99 \mathrm{~m}} \mathrm{Tc}$ complexes. Structure A represents the ternary ligand system, in which tricine and TPPTS are used as coligands to stabilize the ${ }^{99 m}$ Tc-HYNIC core. Structure B represents the HYNIC-K(NIC) chelating system with tricine as coligand to complete the octahedral coordination sphere of technetium. In this way, the highly charged TPPTS is eliminated. Structure $\mathbf{C}$ represents the (HYNIC) ${ }_{2} \mathrm{~K}$ chelating system, in which one HYNIC is monodentate and the other is bidentate while tricine is tridentate. The biomolecule (BM) is a cyclic RGD peptide or non-peptide receptor ligand. The small letter "f" in cyclic peptides represents D-phenylalanine. 


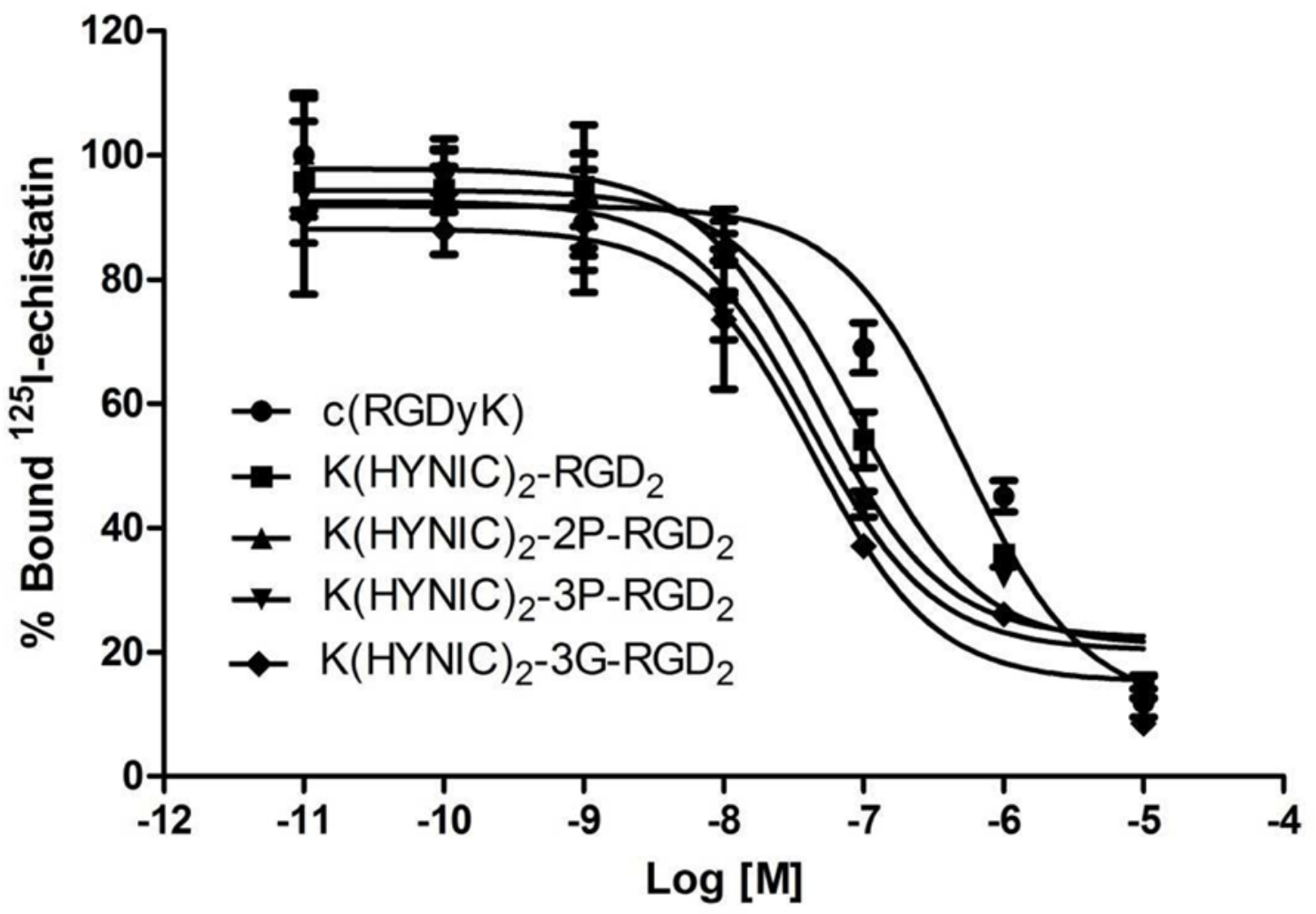

Figure 2.

The competitive inhibition curves of ${ }^{125}$ I-echistatin bound to U87MG glioma cells in the presence of increasing concentrations of cyclic RGD peptide. Their $\mathrm{IC}_{50}$ values were calculated to be $47 \pm 2,35 \pm 2,37 \pm 2,85 \pm 1$ and $422 \pm 15 \mathrm{nM}$ for $\mathrm{K}(\mathrm{HYNIC})_{2}-2 \mathrm{P}-\mathrm{RGD}_{2}$, $\mathrm{K}(\mathrm{HYNIC})_{2}-3 \mathrm{P}-\mathrm{RGD}_{2}, \mathrm{~K}(\mathrm{HYNIC})_{2}-3 \mathrm{G}-\mathrm{RGD}_{2}, \mathrm{~K}(\mathrm{HYNIC})_{2}-\mathrm{RGD}_{2}$ and $\mathrm{c}(\mathrm{RGDyK})$, respectively. The integrin $a_{v} \beta_{3}$ binding affinity follows the order: $\mathrm{K}(\mathrm{HYNIC})_{2}-3 \mathrm{G}-\mathrm{RGD}_{2} \sim$ $\mathrm{K}(\mathrm{HYNIC})_{2}-2 \mathrm{P}-\mathrm{RGD}_{2} \sim \mathrm{K}(\mathrm{HYNIC})_{2}-3 \mathrm{P}-\mathrm{RGD}_{2}>\mathrm{K}(\mathrm{HYNIC})_{2}-\mathrm{RGD}_{2} \gg \mathrm{c}(\mathrm{RGDfK})$. 

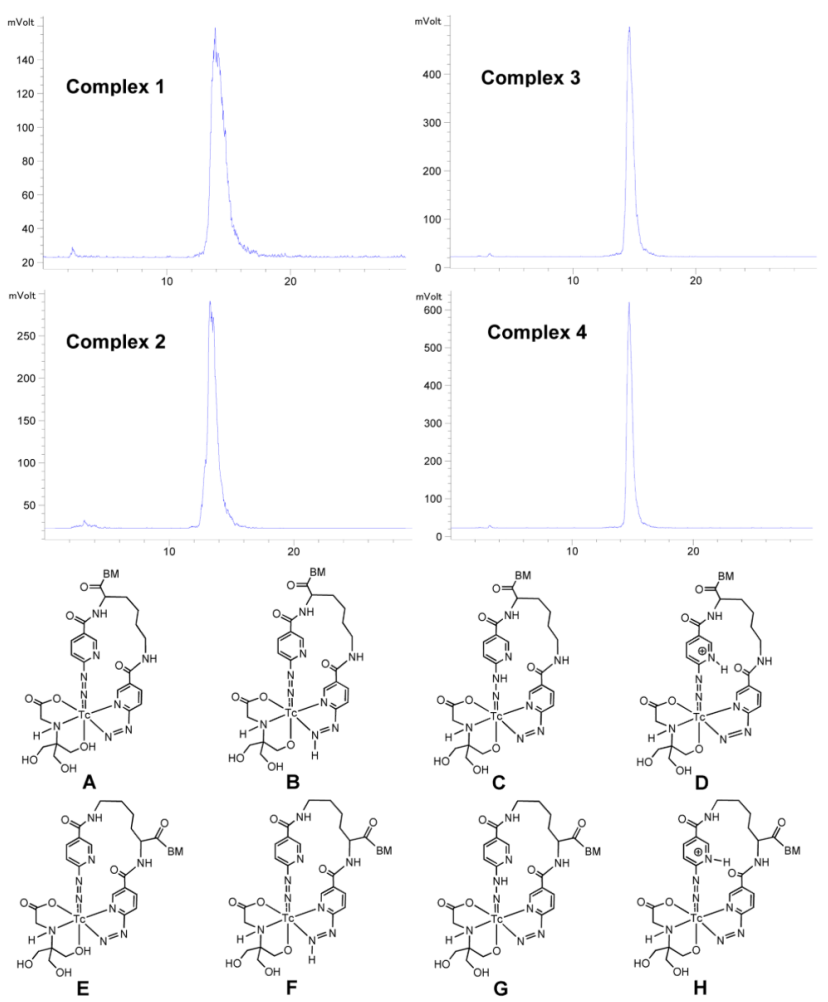

Figure 3.

Top: Radio-HPLC chromatograms of $\mathbf{1}-\mathbf{4}$. Bottom: Structures of possible isomers $(\mathbf{A}-\mathbf{H})$ in macrocyclic ${ }^{99 \mathrm{~m}} \mathrm{Tc}$ complexes $\left[{ }^{99 \mathrm{~m}} \mathrm{Tc}(\right.$ tricine $\left.)\left((\mathrm{HYNIC}){ }_{2} \mathrm{~K}-\mathrm{BM}\right)\right]\left(\mathrm{BM}=\mathrm{RGD}_{2}, 3 \mathrm{G}-\right.$ $\mathrm{RGD}_{2}, 2 \mathrm{P}-\mathrm{RGD}_{2}$ and $3 \mathrm{P}-\mathrm{RGD}_{2}$ ). 


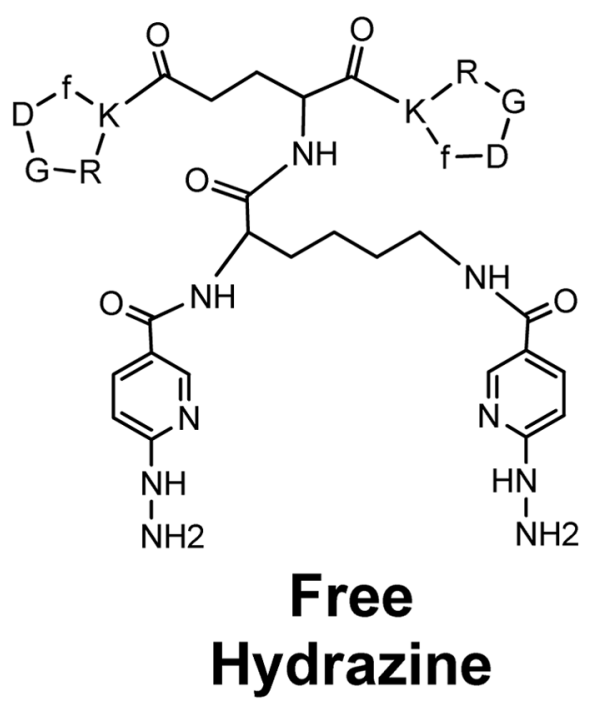

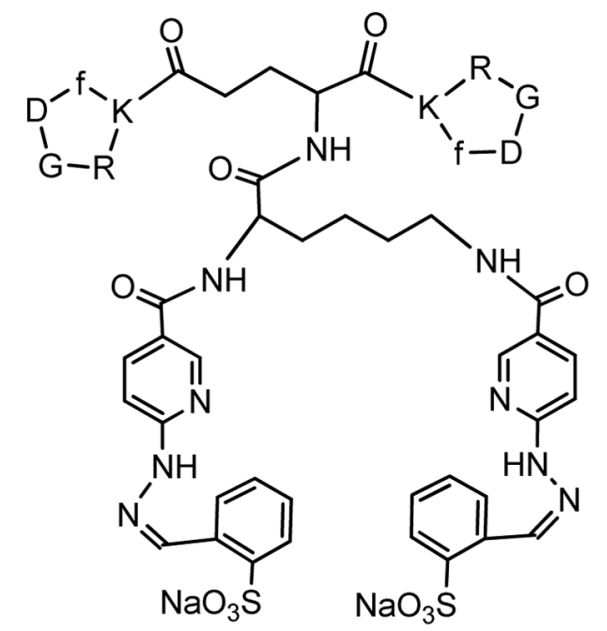

Hydrazone
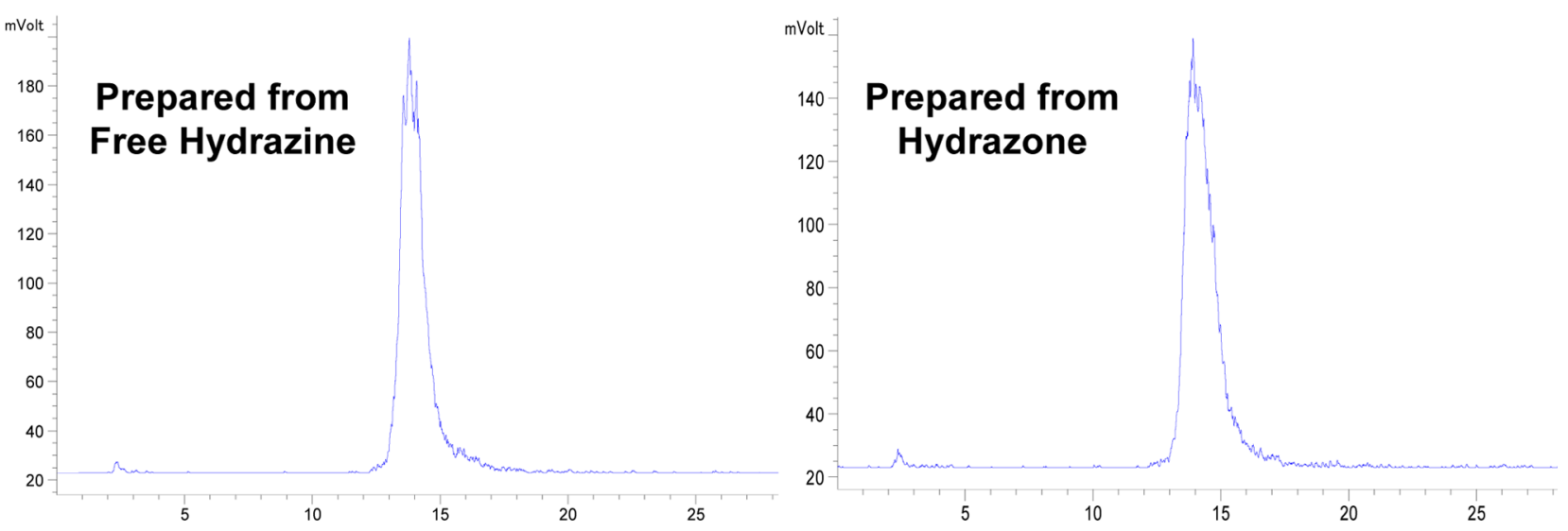

Figure 4.

Representative radio-HPLC chromatograms of $\mathbf{1}$ prepared from free hydrazine (left) and hydrazone (right). The macrocyclic ${ }^{99 \mathrm{~m}} \mathrm{Tc}$ complex prepared from free-hydrazine or hydrazone-protected $\mathrm{K}(\mathrm{HYNIC})_{2}-\mathrm{RGD}_{2}$ had identical radio-HPLC profiles under the same chromatographic conditions, suggesting that both hydrazone-protecting groups in $\mathrm{K}(\mathrm{HYNIC})_{2}-\mathrm{RGD}_{2}$ were removed during ${ }^{99 \mathrm{~m}} \mathrm{Tc}$ chelation. 

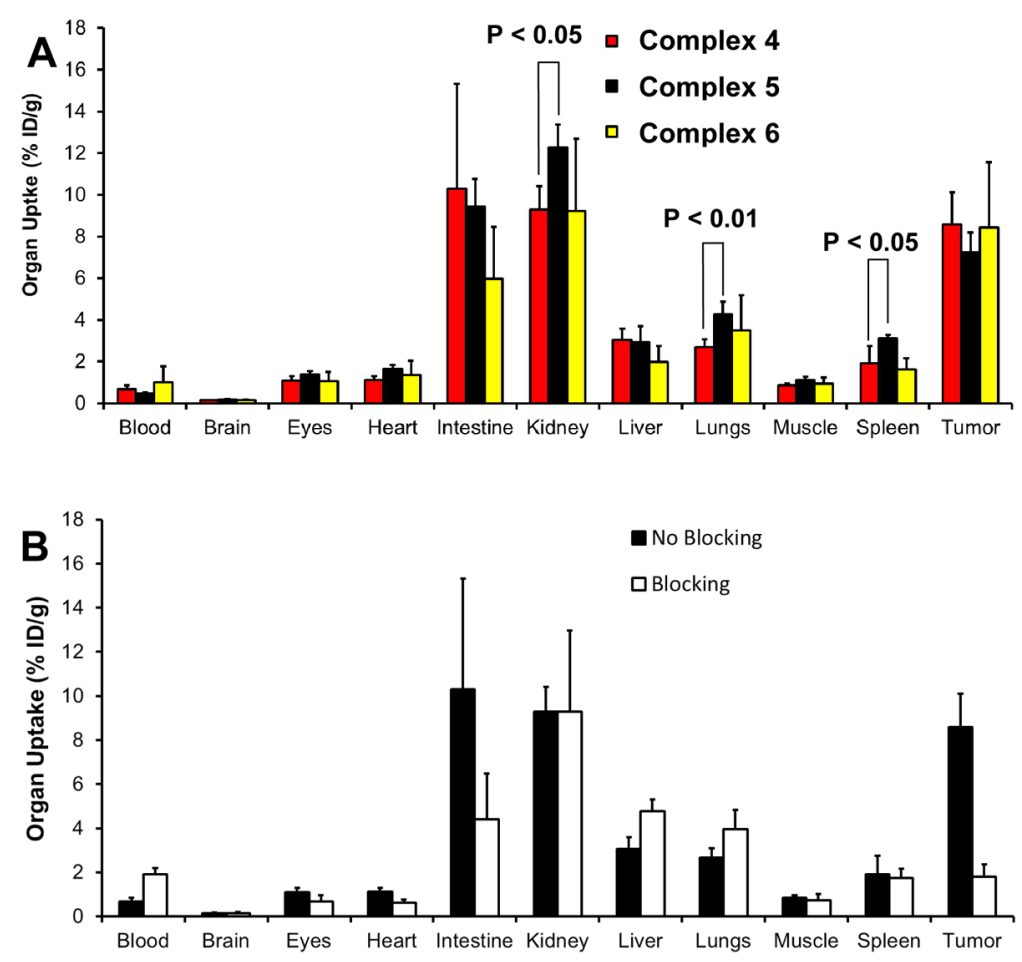

Figure 5.

A: Comparison of 60-min biodistribution data for [ ${ }^{99 \mathrm{~m}} \mathrm{Tc}\left((\mathrm{HYNIC}){ }_{2} \mathrm{~K}-3 \mathrm{P}-\mathrm{RGD}_{2}\right)($ tricine $\left.)\right]$

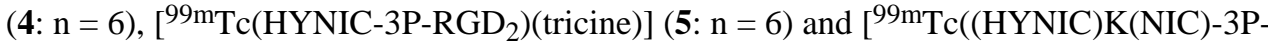
$\left.\mathrm{RGD}_{2}\right)($ tricine $\left.)\right](6: \mathrm{n}=4)$ in athymic nude mice bearing U87MG glioma xenografts to show the impact of ${ }^{99 \mathrm{~m}} \mathrm{Tc}$ chelate on biodistribution properties of ${ }^{99 \mathrm{~m}} \mathrm{Tc}$ radiotracers. $\mathbf{B}$ :

Comparison of the selected 60-min biodistribution data of $\mathbf{4}$ in athymic nude mice $(n=6)$ bearing U87MG glioma xenografts in the absence/presence of excess $\mathrm{E}[\mathrm{c}(\mathrm{RGDfK})]_{2}$ $\left(\mathrm{RGD}_{2}: 350 \mu \mathrm{g} / \mathrm{mouse}\right.$ or $14 \mathrm{mg} / \mathrm{kg}$ ) to demonstrate its specificity in binding to integrin $\alpha_{v} \beta_{3}$. 


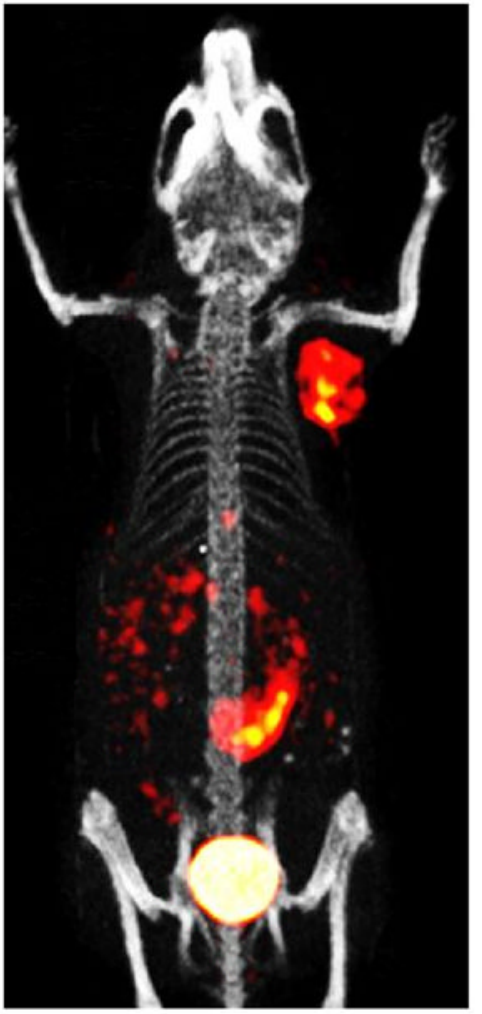

3D

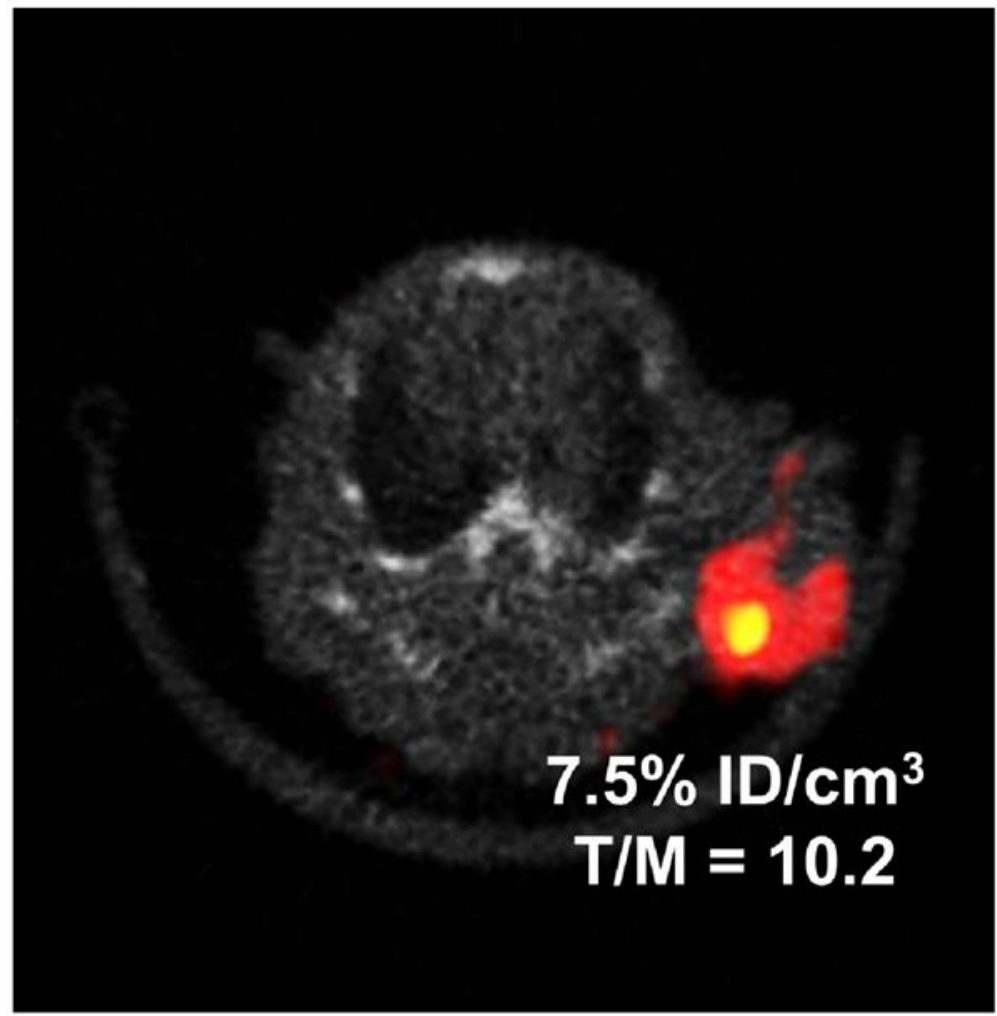

\section{Transverse}

Figure 6.

The 3D and transverse views of SPECT/CT image of an athymic nude mouse bearing U87M human glioma xenografts $\left(\sim 0.2 \mathrm{~cm}^{3}\right)$. The animal was administered with $\sim 50 \mathrm{MBq}$ of 4 . There was no significant radioactivity accumulation in kidneys, liver, lungs, and muscle. However, there was significant radioactivity accumulation in the intestines, which is consistent with the biodistribution data (Table 2). 

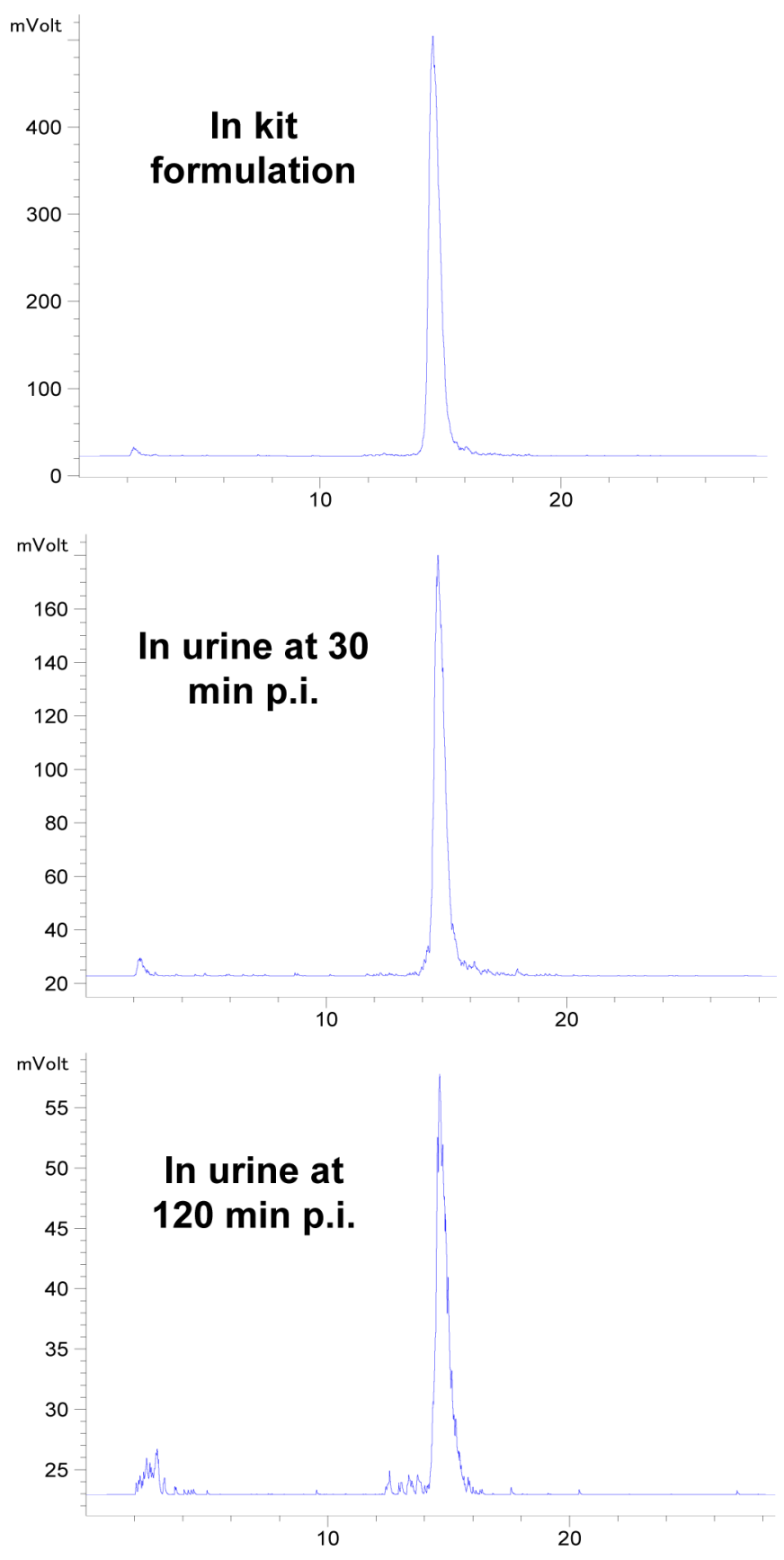

Figure 7.

Representative radio-HPLC chromatograms for radiotracer 4 in the saline before injection, and in the urine at $30 \mathrm{~min}$ and $120 \mathrm{~min}$ p.i. 

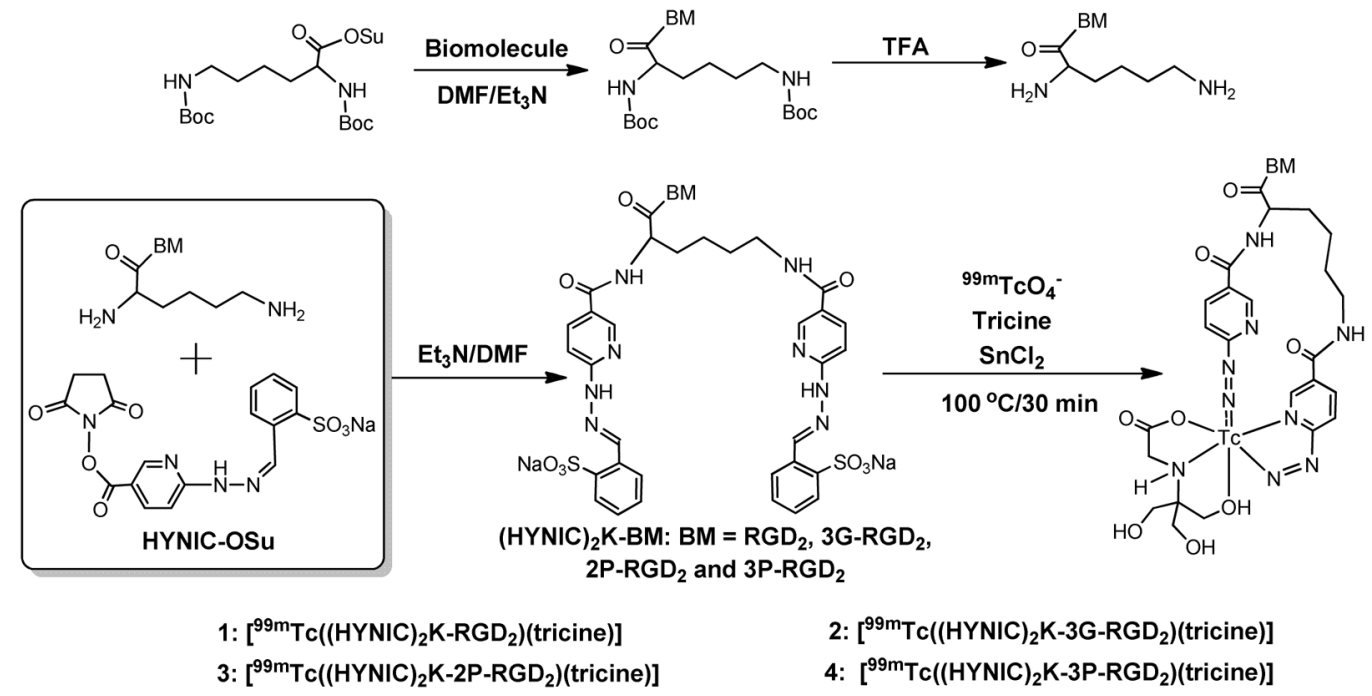

Chart I.

Synthetic scheme for preparation of (HYNIC $)_{2} \mathrm{~K}$-conjugated cyclic RGD peptide dimers and their macrocyclic ${ }^{99 \mathrm{~m}} \mathrm{Tc}$ complexes. 


\section{Table 1}

Radiochemical purity (RCP) and HPLC retention time for ${ }^{99 \mathrm{~m}} \mathrm{Tc}$-radiotracers.

\begin{tabular}{|c|c|c|}
\hline Radiotracer & RCP $(\boldsymbol{\%})$ & HPLC Retention (min) \\
\hline $\mathbf{1}$ & $>90$ & 14.5 \\
\hline $\mathbf{2}$ & $>95$ & 13.8 \\
\hline $\mathbf{3}$ & $>95$ & 14.8 \\
\hline $\mathbf{4}$ & $>95$ & 15.2 \\
\hline
\end{tabular}




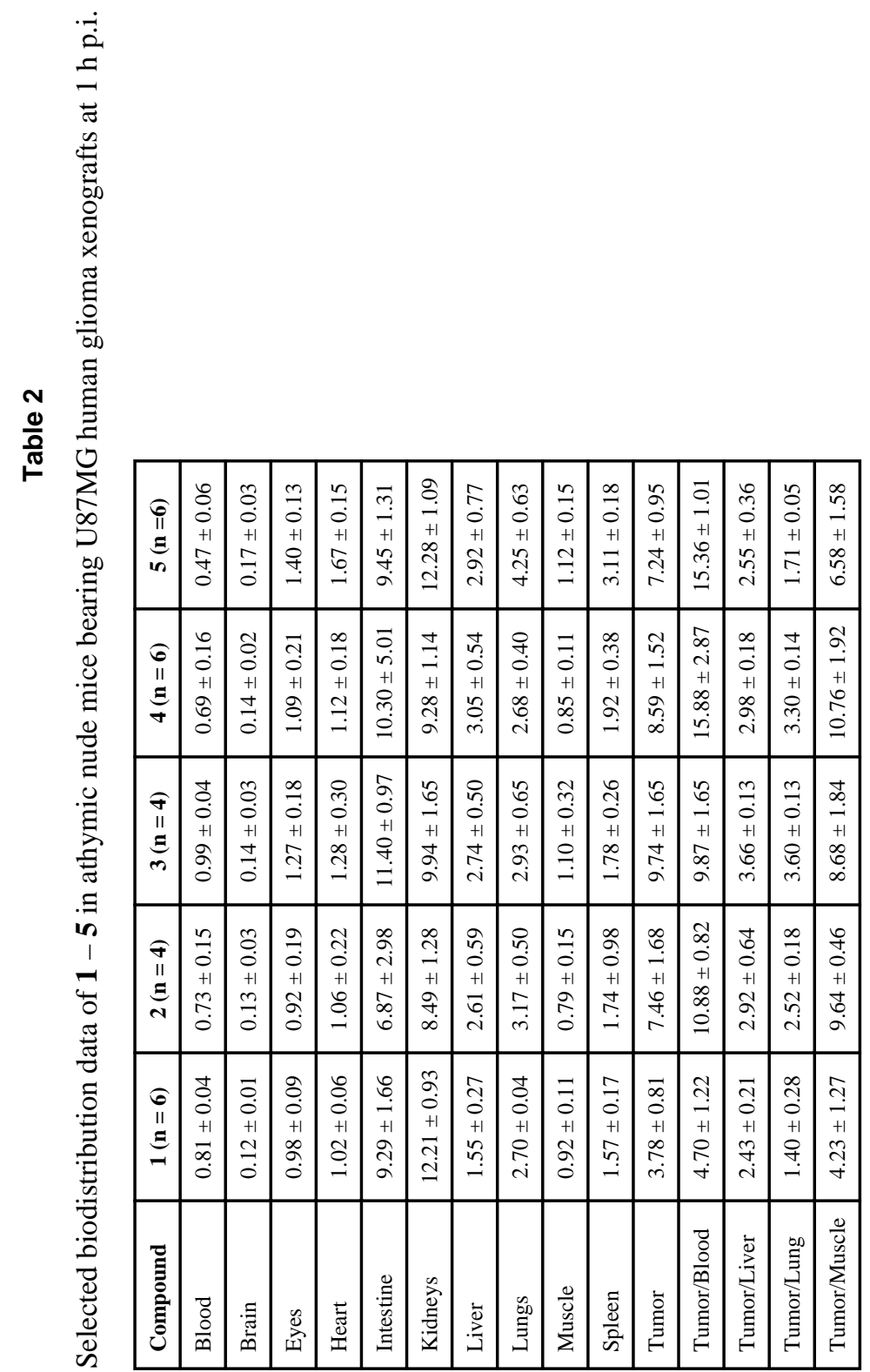

